\title{
How does cannabidiol (CBD) influence the acute effects of delta-9- tetrahydrocannabinol (THC) in humans? A systematic review.
}

Authors: Abigail M. Freeman*a, Katherine Petrillia, Rachel Lees ${ }^{\mathrm{a}, \mathrm{b}}$, Chandni Hindocha $^{\mathrm{a}}$, Claire Mokrysz ${ }^{\mathrm{a}}$, H. Valerie Curran ${ }^{\mathrm{a}}$, Rob Saunders ${ }^{\mathrm{c}}$, Tom P. Freeman ${ }^{\mathrm{a}, \mathrm{b}, \mathrm{d}}$

\section{Affiliations:}

a. Clinical Psychopharmacology Unit, University College London, Gower Street, London, UK, WC1E 6BT

b. Addiction and Mental Health Group (AIM), University of Bath, Bath, UK, BA2 7AY

c. Centre for Outcomes, Research \& Effectiveness (CORE), University College London, Gower Street, London, UK, WC1E 6BT

d. National Addiction Centre, King's College London, London, UK, SE5 8BB

*Corresponding author email: abigail.freeman@ucl.ac.uk

Declarations of interest: none

This research did not receive any specific grant from funding agencies in the public, commercial, or not-for-profit sectors. 


\begin{abstract}
The recent liberalisation of cannabis regulation has increased public and scientific debate about its potential benefits and risks. A key focus has been the extent to which cannabidiol (CBD) might influence the acute effects of delta-9-tetrahydrocannabinol (THC), but this has never been reviewed systematically. In this systematic review of how CBD influences the acute effects of THC we identified 16 studies involving 466 participants. Ten studies were judged at low risk of bias. The findings were mixed, although CBD was found to reduce the effects of THC in several studies. Some studies found that CBD reduced intense experiences of anxiety or psychosis-like effects of THC and blunted some of the impairments on emotion and reward processing. However, CBD did not consistently influence the effects of THC across all studies and outcomes. There was considerable heterogeneity in dose, route of administration and THC:CBD ratio across studies and no clear dose-response profile emerged. Although findings were mixed, this review suggests that CBD may interact with some acute effects of THC.
\end{abstract}




\section{Introduction}

In the last decade, there have been substantial changes to cannabis regulation, with many countries adopting a more permissive stance towards medical and recreational use (Kilmer, 2017). The World Health Organisation recently proposed the rescheduling of cannabis and its removal from the schedule IV category in light of the drug's medicinal properties (Mayor, 2019). Cannabis and cannabinoids have the potential to treat several medical conditions including chronic pain, treatment-resistant epilepsy, and nausea and vomiting due to chemotherapy (T. P. Freeman, Hindocha, Green, \& Bloomfield, 2019). However, over 60 years of prohibition and associated regulatory barriers to researching this field (Nutt, 2015) means there are significant gaps in our knowledge about the clinical benefits and potential harms (Hall, Hoch, \& Lorenzetti, 2019). Recently, there has been renewed interest in whether the composition of the different cannabinoids within cannabis may improve its safety profile while enhancing medicinal efficacy (McPartland \& Russo, 2014).

The cannabis plant (Cannabis Sativa L.) produces over 140 different compounds known as phytocannabinoids and terpenoids (Hanuš, Meyer, Muñoz, Taglialatela-Scafati, \& Appendino, 2016), many of which directly modulate the endogenous cannabinoid system in humans ( $\mathrm{Lu} \&$ Mackie, 2016). The endocannabinoid system consists of at least two types of cannabinoid receptors $\left(\mathrm{CB}_{1}\right.$ and $\mathrm{CB}_{2}$ ) and endogenous ligands (endocannabinoids such as anandamide and 2arachidonoylglycerol) that bind to these receptors and ligand metabolic enzymes. Cannabinoid receptors are as abundant as glutamate, gamma-aminobutyric acid (GABA), or dopamine receptors in the brain (Katona \& Freund, 2012), and consequently are involved in a wide range of functions including regulation of mood, memory and reward processing (Bossong, Jansma, Bhattacharyya, \& Ramsey, 2014; 
Curran et al., 2016). $\mathrm{CB}_{1}$ receptors are primarily located in central and peripheral neurons and mediate the release of transmitters at the synaptic terminal, including acetylcholine, noradrenaline, dopamine, 5-hydroxytryptamine (5-HT), GABA, glutamate, D-aspartate and cholecystokinin. Inside and outside of the central nervous system, $\mathrm{CB}_{2}$ receptors are predominant in the immune system and have a role in altering the release of chemical messengers, cytokines, and the modulation of immune cell migration (Pertwee, 2008).

Two of the most widely researched cannabinoids are delta-9tetrahydrocannabinol (THC), and cannabidiol (CBD), which have contrasting mechanisms of action and effect profiles. THC and CBD concentrations vary across different types of cannabis products used for recreational (T. P. Freeman et al., 2014) and medicinal purposes (T. P. Freeman et al., 2019). Although some strains of cannabis contain both THC and CBD in similar quantities, concentrations of THC in cannabis doubled over the past ten years (T. P. Freeman, Groshkova, et al., 2018). CBD content, which may attenuate the effects of THC, has become nearly obsolete in illicit samples of the drug across Europe and the USA (Chandra et al., 2019; Potter, Hammond, Tuffnell, Walker, \& Di Forti, 2018).

\subsection{Pharmacology of THC and CBD}

The pharmacology of THC, although reasonably well understood, is complex. THC interacts with several pharmacological targets (see Pertwee and Cascio (2014) for a review). THC is a partial cannabinoid receptor agonist acting on both $\mathrm{CB}_{1}$ and $\mathrm{CB}_{2}$ and can behave as both an agonist and antagonist at the $\mathrm{CB}_{1}$ receptor. Although THC acts primarily through the neuronal presynaptic $\mathrm{CB}_{1}$ receptors to inhibit ongoing 
neurotransmitter release. Repeated administration of THC may give rise to tolerance to its effects and the action of endocannabinoids (Colizzi \& Bhattacharyya, 2018; Pertwee, 2008).

CBD differs from THC in several important ways. CBD has no intoxicating properties at typical doses (Pertwee, 2008). CBD has minimal direct activity at $\mathrm{CB}_{1}$ and $\mathrm{CB}_{2}$ receptors, having low affinity for both receptor subtypes (Thomas et al., 2007). Unlike THC, which acts at the orthosteric site of $\mathrm{CB}_{1}$ receptors, $\mathrm{CBD}$ is a negative allosteric modulator that can alter the potency and efficacy of the orthosteric ligand without activating the receptor (Hayakawa et al., 2008; Laprairie, Bagher, Kelly, \& Denovan-Wright, 2015). This may explain preclinical findings which suggest that, when administered together, CBD may counteract some of the actions of THC, while also potentiating other actions of THC (McPartland \& Russo, 2014). CBD has also been shown to modulate $5 \mathrm{HT}_{1 \mathrm{~A}}$ (Ross, 2007; Russo, Burnett, Hall, \& Parker, 2005) and PPAR $\gamma$ (Campos, Moreira, Gomes, Del Bel, \& Guimaraes, 2012) as an agonist, GPR55 as an antagonist (Ryberg et al., 2007), and to inhibit the hydrolysis and reuptake of the Fatty Acid Amide Hydrolase enzyme (Bisogno et al., 2001).

\subsection{Acute effects of THC}

When acutely administered, THC induces a broad range of transient and dosedependent effects. THC causes psychotropic effects of cannabis, inducing the "high" or "stoned" effect associated with its ingestion (Gaoni \& Mechoulam, 1964). THC is associated with a dose-dependent increase in heart rate (Karniol \& Carlini, 1973; Zuurman et al., 2008). Although many studies have investigated the subjective effects of THC, there has been considerable variation in doses, routes of administration and 
outcomes used. THC induces appetitive effects including wanting more of the drug and liking the drug's effects (Curran, Brignell, Fletcher, Middleton, \& Henry, 2002). It reduces anxiety at low doses, but increases anxiety at higher doses (Hunault et al., 2009) and has been shown to robustly reduce alertness (Zuurman et al., 2008). However, these effects can vary between individuals and within individuals on different occasions of use (Green, Kavanagh, \& Young, 2003). THC produces transient psychosis-like effects (D'Souza et al., 2004; Morrison \& Stone, 2011; Morrison et al., 2009), which may be enhanced in individuals prone to psychosis (Mason et al., 2009). THC also interferes with several behavioural and cognitive processes impairing episodic memory, attention and working memory (Ranganathan \& D’Souza, 2006; Volkow et al., 2016). Functional imaging studies have shown that THC disrupts the neural correlates of emotional processes, executive function and reward function (Bloomfield et al., 2018).

\subsection{Acute effects of CBD}

Originally believed to have a minimal effect due to its lack of subjective effects, CBD has recently received renewed interest for its potential therapeutic properties (Khoury et al., 2019; Zuardi, 2008). Few studies have investigated the acute effects of CBD, and the results of these studies have been mixed. Some studies report that low doses of CBD (30mg oral; 25mg IV respectively) has no intoxicating effects (Hollister, 1973; Perez-Reyes, Timmons, Davis, \& Wall, 1973). However, in a small double-blind crossover study (n=7), Zuardi, Guimaraes, and Moreira (1993) found that CBD (300mg oral) acutely increased somnolence and reduced anxiety and two studies found that CBD (200mg oral; 400mg vaporised respectively) produced mood altering and subjective intoxicating effects (Leweke, Schneider, Radwan, Schmidt, \& Emrich, 
2000; Solowij et al., 2019). CBD (400-600mg oral) administered alone is also associated with anxiolytic effects (Crippa et al., 2011; Hundal et al., 2018; Zuardi et al., 1993), however, in a recent study of emotional processing tasks, CBD (300-900mg oral) induced minimal behavioural and subjective effects (Arndt \& De Wit, 2017). CBD (32mg vaporised) has been shown to enhance consolidation of fear extinction learning in humans (Das et al., 2013), which suggests its effects on emotional processing may be nuanced and related to other cognitive processes. Several studies have investigated chronic administration of CBD for a range of therapeutic indications including as an antiepileptic, anxiolytic, antipsychotic and neuroprotective drug (for a review see White, 2019; and Whiting et al., 2015).

\subsection{The interaction between THC and CBD}

A much debated question is whether, when administered together, CBD interacts with THC's effects. Some researchers have suggested that CBD can influence the effects of THC, increasing its clinical efficacy and reducing harmful effects (Ben-Shabat et al., 1998; Bonn-Miller, ElSohly, Loflin, Chandra, \& Vandrey, 2018; Russo \& McPartland, 2003). Some studies have demonstrated this effect, for example: evidence from survey data (Schubart et al., 2011), and naturalistic hair analysis studies suggests that increased $\mathrm{CBD}$ content in cannabis may be protective against various memoryimpairing effects and psychosis-like experiences associated with cannabis use (Demirakca et al., 2011; Morgan \& Curran, 2008; Morgan et al., 2011). Another naturalistic study, where cannabis users smoked their own cannabis which was later analysed for THC and CBD content, found that high CBD content was associated with reduced impairment of verbal memory and a reversal of attentional bias towards 
cannabis and food cues (Morgan, Freeman, Schafer, \& Curran, 2010; Morgan, Schafer, Freeman, \& Curran, 2010).

Evidence from repeated dosing studies is more mixed. One parallel group, randomised controlled trial $(n=177)$ study in patients with intractable cancer-related pain showed that a combination of THC $(2.7 \mathrm{mg})$ and CBD $(2.5 \mathrm{mg})$ in an oromucosal spray produced a significant improvement on a pain rating scale compared to placebo, whereas the THC $(2.7 \mathrm{mg})$ group showed no significant change. Twice as many patients (43\% of patients) taking THC and CBD showed a $30 \%$ pain reduction (on a 0-10 Numerical Rating Scale) from baseline compared to placebo (21\% of patients) (Johnson et al., 2010). Others, however, have found THC alone to be more clinically effective than a combination of the two in chronic pain, fibromyalgia and neuropathic pain (Notcutt et al., 2004; van de Donk et al., 2019; Wade, Robson, House, Makela, \& Aram, 2003).

Much uncertainty also exists around whether CBD alters the pharmacokinetic profile of THC (Lucas, Galettis, \& Schneider, 2018). For example, while Agurell et al. (1981) found that co-administration of CBD with THC did not alter the pharmacokinetics of THC, van de Donk et al. (2019) showed that plasma concentrations of THC were higher than expected when a treatment containing both THC (13.4mg) and CBD (17.8mg) was administered compared to a treatment containing THC (22.4mg) and CBD (1mg).

Previous non-systematic reviews have suggested that CBD may attenuate the acute harmful effects of THC (Colizzi \& Bhattacharyya, 2017; Englund, Freeman, Murray, \& McGuire, 2017; Niesink \& van Laar, 2013) while potentiating its positive 
effects (Russo, 2019; Russo \& Guy, 2006). One systematic review investigating whether CBD has antipsychotic effects found that CBD may offset the psychosis-like effects of THC (Iseger \& Bossong, 2015). Although several narrative reviews have discussed the question of whether CBD interacts with THC when administered together acutely, this question has never been reviewed systematically. This systematic review aimed to establish how CBD influences the acute effects of THC in humans.

\section{Methods}

\subsection{Protocol and registration}

This review was conducted according to Preferred Reporting Items for Systematic reviews and Meta-Analyses (PRISMA) guidelines (Liberati et al., 2009) and a checklist is provided in Appendix A. The protocol (Appendix B) and registration for the current systematic review was prospectively registered (PROSPERO: CRD42019126994) on $28^{\text {th }}$ February 2019 (A. M. Freeman et al., 2019).

\subsection{Eligibility criteria}

\subsubsection{Inclusion criteria}

a) A condition or group in which THC is acutely administered.

b) A matched condition or group where the same dose of THC is acutely administered together with cannabidiol (CBD), under experimental conditions.

c) THC must be delivered via the same route of administration in both conditions, as different routes (e.g., oral THC alone versus intravenous THC combined with CBD) may lead to a different profile of effects related to different pharmacokinetics and metabolism of the drug, as well as the interaction between the compounds. 
d) The studies must include either a placebo condition or a control condition where there is no drug administered, for example, a pre-drug measurement or baseline measurement. This is necessary to evaluate the acute effects of THC.

e) The included papers must be peer-reviewed.

f) Articles must be published in English.

\subsubsection{Exclusion criteria}

a) Conference extracts or abstracts, theses, reviews, supplements, editorial reports, correspondence, non-peer reviewed material, e.g. books extracts, notes, and letters.

b) Studies where there was no matched dose and route of administration for THC, with and without CBD.

c) Repeated dosing studies.

d) Studies where the statistical analysis did not directly compare either 1) THC alone to a matched dose of THC with CBD, or 2) THC to placebo, and a matched dose of THC with CBD and placebo.

e) Studies not including humans.

\subsection{Information sources}

A systematic search was conducted on $28^{\text {th }}$ February 2019 using the following electronic bibliographic databases: MEDLINE, EMBASE, PsycINFO, and CINAHL Plus. The search strategy included only terms relating to or describing the intervention (THC and CBD). The terms were combined with the Ovid filter for human studies and studies published in English. The search terms were adapted for use for each bibliographic database and run in combination with database-specific filters for human 
trials and peer-reviewed articles, where these were available. The search terms and results are provided in Appendix C.

\subsection{Study selection}

The titles and abstracts of studies retrieved using the search strategy, and those from additional sources, were screened independently by two reviewers (AF and RL) to identify studies that potentially met the inclusion criteria outlined above. The full text of these potentially eligible studies was retrieved and independently assessed for eligibility by two review team members (AF and KP). Any disagreement between them over the eligibility of particular studies was resolved through discussion with a third reviewer (TF).

\subsection{Data collection process and data items}

A standardised, pre-piloted form (in Microsoft Excel) was used to extract data from the included studies for assessment of study quality and evidence synthesis (Appendix D). This form was adapted from the Cochrane Collaboration's Data collection form for intervention review - randomised controlled trials (RCT). Through the development process, some irrelevant sections were removed from the original form and new sections added. The extracted information included: study setting; study population and details of the dose and route of administration for THC and CBD; THC:CBD ratio; study methodology; recruitment and study completion rates; outcomes and times of measurement; information for the assessment of the risk of bias. Two reviewers (AF and KP) extracted the data, and discrepancies were resolved through discussion with a third reviewer $(\mathrm{CH})$ where necessary. A subset of the extracted data was randomly checked by another reviewer $(\mathrm{CH})$. 


\subsection{Risk of bias in individual studies}

Two reviewers (AF and KP) independently assessed the risk of bias in included studies by considering the criteria set out by the Cochrane's Risk of Bias (RoB2) assessment tools as appropriate for the study design (Higgins et al., 2011). Disagreements between the reviewers over the risk of bias in particular studies were resolved by discussion, with the involvement of a third review author $(\mathrm{CH})$ where necessary.

\subsection{Risk of bias across studies}

This review assessed the risk of publication bias by considering the different types of bias laid out in the Cochrane Handbook for Systematic Reviews of Interventions (Higgins \& Green, 2008; Higgins et al., 2016).

\subsection{Summary measures}

It was acknowledged that the included studies would have investigated a variety of outcome measures and therefore this review planned to take an inclusive approach and report all outcomes where the effects of THC alone were compared to the effects of the same dose of THC combined with CBD.

\section{Results}

The initial search on $28^{\text {th }}$ February 2019 identified 1808 records, of which 601 were duplicates and excluded. Four additional articles were identified as they were published after the initial search. The abstract and title of 1211 articles were reviewed, and 47 articles were considered potentially relevant and subject to full-text searching. Study selection procedures yielded 23 published articles reporting on 16 studies which met the inclusion criteria. A table summarising the excluded studies is provided in 
Appendix E. Figure 2 displays a flow diagram of the reasons for exclusion at each stage (Appendix F).

\subsection{Study characteristics}

Altogether, 16 studies reported in 23 articles were included in this review (Arkell et al., 2019; Bhattacharyya et al., 2010; Bird et al., 1980; Dalton, Martz, Lemberger, Rodda, \& Forney, 1976; Englund et al., 2013; T. P. Freeman, Pope, et al., 2018; Guy \& Robson, 2003; Haney et al., 2016; Hindocha et al., 2015; Hollister \& Gillespie, 1975; Hunt, Jones, Herning, \& Bachman, 1981; Juckel, Roser, Nadulski, Stadelmann, \& Gallinat, 2007; Karniol, Shirakawa, Kasinski, Pfeferman, \& Carlini, 1974; Lawn et al., 2016; Morgan et al., 2018; Nadulski et al., 2005; Nicholson, Turner, Stone, \& Robson, 2004; Roser et al., 2009; Roser et al., 2008; Stadelmann et al., 2011; Zuardi, Shirakawa, Finkelfarb, \& Karniol, 1982). Table 1 provides details of each study's aims, the participants and their cannabis use history, the intervention groups, and outcome measures.

All studies were experimental human laboratory studies. Only three studies (Bird et al., 1980; Englund et al., 2013; Karniol \& Carlini, 1974) used parallel group designs, and the rest used a crossover design. Study sample sizes varied between 4 and 155 participants, with a total of 466 participants. Some studies were explicitly designed to evaluate drug safety and pharmacokinetics, and were therefore not powered to detect treatment effects (Guy \& Robson, 2003; Hunt et al., 1981). One parallel group study (Karniol et al., 1974) and five crossover-design studies (Bhattacharyya et al., 2010; Dalton et al., 1976; Hunt et al., 1981; Nicholson et al., 2004; Zuardi et al., 1982) had 
less than 10 participants (4-8) per treatment cell and therefore may not be powered to detect smaller effect sizes (Simmons, Nelson, \& Simonsohn, 2011). 
Table 1 Summary of Study Characteristics and Findings

\begin{tabular}{|c|c|c|c|c|c|c|c|}
\hline $\begin{array}{l}\text { Study and } \\
\text { location }\end{array}$ & Aim & Participants & Design & *Intervention & Outcomes & Main findings & $\begin{array}{l}\text { Risk of } \\
\text { Bias }\end{array}$ \\
\hline $\begin{array}{l}\text { Arkell et al. } \\
(2019), \\
\text { Australia }\end{array}$ & $\begin{array}{l}\text { To compare the } \\
\text { subjective, cognitive, } \\
\text { and driving-related } \\
\text { effects of vaporized } \\
\text { THC, and THC and } \\
\text { CBD combined. }\end{array}$ & $\begin{array}{l}14 \text { healthy volunteers (three } \\
\text { women; } 11 \text { men) } 21-38 \\
\text { years with self-reported } \\
\text { cannabis use } \leq 2 \text { times a } \\
\text { week for three months and } \\
\text { lifetime use } \geq 10 \text { times } \\
\text { Three participants did not } \\
\text { complete, one withdrew, } \\
\text { one did not comply with the } \\
\text { protocol and another was } \\
\text { discharged due to elevated } \\
\text { blood pressure and heart } \\
\text { rate. No illicit drugs for } \\
\text { duration of the study. } \\
\text { Breathalyser and oral fluid } \\
\text { screening for recent alcohol } \\
\text { and drug use on each day. }\end{array}$ & $\begin{array}{l}\text { Placebo- } \\
\text { controlled, double- } \\
\text { blind, crossover } \\
\text { study across three } \\
\text { treatment } \\
\text { conditions. } \\
\text { Randomized and } \\
\text { counterbalanced } \\
\text { order. } \\
\end{array}$ & $\begin{array}{l}\text { Vaporised THC } \\
3.75 \mathrm{mg}+ \\
\text { CBD } 13.75 \mathrm{mg} ; \\
\text { vaporised THC } \\
13.75 \mathrm{mg}+ \\
\mathrm{CBD}<1.25 \\
\mathrm{mg} ; \text { vaporised } \\
\text { Placebo }<1.25 \\
\text { mg THC/CBD }\end{array}$ & $\begin{array}{l}\text { DAT driving } \\
\text { simulation task, } \\
\text { DSST, PASAT, } \\
\text { pharmacokinetics, } \\
\text { self-rating of } \\
\text { subjective } \\
\text { intoxicating effects. }\end{array}$ & $\begin{array}{l}\text { Peak plasma concentrations of } \\
\text { THC higher in THC+CBD } \uparrow \\
\text { No difference in self-rated } \\
\text { subjective intoxication or } \\
\text { confidence to drive for THC } \\
\text { and THC+CBD = } \\
\text { STAI and anxious self-rating } \\
\text { was increased in both THC and } \\
\text { THC+CBD at } 15 \text { mins but not } \\
\text { THC+CBD at } 1 \text { hour }=/ \downarrow \\
\text { Car following task both THC } \\
\text { and THC+CBD impaired SDLP } \\
= \\
\text { THC with CBD impaired } \\
\text { performance on the DAT } \\
\text { compared to THC or placebo } \uparrow\end{array}$ & Low \\
\hline $\begin{array}{l}\text { Bhattachary } \\
\text { ya et al. } \\
(2010), \\
\text { United } \\
\text { Kingdom }\end{array}$ & $\begin{array}{l}\text { To investigate whether } \\
\text { pre-treatment with } \\
\text { CBD can prevent THC } \\
\text { from provoking } \\
\text { psychotic symptoms. }\end{array}$ & $\begin{array}{l}\text { Six healthy volunteers } \\
\text { (three women; three men) } \\
\text { r21-42 years, with mean } \\
\text { lifetime self-reported } \\
\text { Ccannabis use } 150 \text { times; } \\
\text { minimal exposure to other } \\
\text { illicit drugs. Negative } \\
\text { urinary drug screen before } \\
\text { each testing session. }\end{array}$ & $\begin{array}{l}\text { Placebo- } \\
\text { controlled, double- } \\
\text { blind, crossover } \\
\text { study, across two } \\
\text { treatment } \\
\text { conditions. } \\
\text { Pseudo- } \\
\text { randomisation. }\end{array}$ & $\begin{array}{l}\text { Pre-treatment } \\
\text { (T-5mins) } \\
\text { intravenous } \\
\text { CBD } 5 \mathrm{mg} \\
\text { followed by } \\
\text { intravenous } \\
\text { THC } 1.25 \mathrm{mg} \text {; } \\
\text { pre-treatment } \\
\text { (T-5mins) } \\
\text { intravenous } \\
\text { Placebo }\end{array}$ & $\begin{array}{l}\text { PANSS, } \\
\text { pharmacokinetics. }\end{array}$ & $\begin{array}{l}\text { No significant difference in } \\
\text { blood levels of THC with or } \\
\text { without pre-treatment with } \\
\text { CBD = } \\
\text { THC increases psychotic } \\
\text { symptoms on PANSS in three } \\
\text { participants; pre-treatment (T- } \\
210 \text { mins) with CBD but not } \\
\text { placebo CBD blocks the } \\
\text { emergence of these in all three } \\
\text { volunteers } \downarrow\end{array}$ & Low \\
\hline
\end{tabular}


161 recruited (39 women;

122 men, six excluded

Placebo-

To examine the effect following breathalyser); 18-controlled, doubleof all of the possible 36 years, whom $50 \%$ self- blind, parallel

Bird et al. combinations between reported cannabis use at study across 16 $(1980)^{\mathrm{a}}$, ethanol and the major least once a week;

treatment

Australia

constituents of

experience varied from 1- conditions.

cannabis, in one

13years, with a median of Randomly

experimental design. 3.8 years. Breathalyser to assigned to

confirm no presence of treatment group. alcohol on test day. (n)
Placebo-

controlled, double-

blind, crossover

\begin{tabular}{|c|c|c|c|c|c|c|c|}
\hline $\begin{array}{l}\text { Dalton et al. } \\
(1976), \\
\text { United } \\
\text { States }\end{array}$ & $\begin{array}{l}\text { To evaluate the } \\
\text { interaction between } \\
\text { THC and CBD in } \\
\text { typical doses used by } \\
\text { cannabis smokers. }\end{array}$ & $\begin{array}{l}16 \text { healthy volunteers } \\
\text { (men) } 21-24 \text { years, with } \\
\text { self-reported cannabis use } \\
\text { at least once, but never } \\
\text { regular use. Abstinence not } \\
\text { reported. }\end{array}$ & $\begin{array}{l}\text { study with four } \\
\text { treatment } \\
\text { conditions. } \\
\text { Randomised } \\
\text { treatment order } \\
\text { using Latin } \\
\text { Squares. One } \\
\text { participant } \\
\text { withdrew. }\end{array}$ & $\begin{array}{l}\text { Smoked THC } \\
0.025 \mathrm{mg}+ \\
\text { CBD 0.150 } \\
\mathrm{mg} / \mathrm{kg} ; \text { smoked } \\
\text { THC 0.025mg; } \\
\text { smoked } \\
\text { Placebo }\end{array}$ & $\begin{array}{l}\text { Blood pressure, } \\
\text { CMI, DAF, heart } \\
\text { rate mental } \\
\text { coordination (peg- } \\
\text { board), modified } \\
\text { pursuit meter, } \\
\text { wobble board. }\end{array}$ & $\begin{array}{l}\text { 'high' associated with THC } \\
\text { alone } \downarrow \\
\text { CBD did not alter the effects of } \\
\text { THC standing steadiness, hand- } \\
\text { eye coordination, manual } \\
\text { coordination, heart rate, and } \\
\text { performance on a delayed } \\
\text { auditory feedback task = }\end{array}$ & Low \\
\hline $\begin{array}{l}\text { Dalton et al. } \\
(1976), \\
\text { United } \\
\text { States }\end{array}$ & $\begin{array}{l}\text { To evaluate the } \\
\text { interaction between } \\
\text { THC and CBD in } \\
\text { doses typical of doses } \\
\text { being used by } \\
\text { cannabis smokers. }\end{array}$ & $\begin{array}{l}\text { Eight healthy volunteers } \\
\text { (men) 21-24 years, with } \\
\text { self-reported cannabis use } \\
\text { at least once, but never } \\
\text { regular use. Abstinence not } \\
\text { reported. }\end{array}$ & $\begin{array}{l}\text { Placebo- } \\
\text { controlled, double- } \\
\text { blind, crossover } \\
\text { study with two } \\
\text { treatment } \\
\text { conditions. } \\
\text { Randomised using } \\
\text { Latin Squares } \\
\text { design. }\end{array}$ & $\begin{array}{l}\text { Pre-treatment } \\
\text { (T-30mins) oral } \\
\text { CBD } \\
0.150 \mathrm{mg} / \mathrm{kg} \\
\text { followed by } \\
\text { smoked THC } \\
0.025 \mathrm{mg} / \mathrm{kg} \text {; } \\
\text { smoked THC } \\
0.025 \mathrm{mg} / \mathrm{kg} \text {; }\end{array}$ & $\begin{array}{l}\text { CMI, blood pressure, } \\
\text { heart rate. }\end{array}$ & $\begin{array}{l}\text { Pre-treatment with CBD did not } \\
\text { alter the effects of THC on any } \\
\text { measure = }\end{array}$ & Low \\
\hline
\end{tabular}

Auditory and

complex reaction

times, conjunctival

hyperaemia, pulse

Oral THC

$0.215 \mathrm{mg} / \mathrm{kg}+$ rates, the pursuit-

CBD 0.320 rotor (errors and

THC, where THC reduced

time off target), self- performance on perceptual,

rating of subjective cognitive and motor function

tests and increased pulse rate,

conjunctival hyperaemia and

subjective intoxication $=$

standing steadiness

(eyes open and

closed), visual,

VDA.

(n)

When co-administered CBD
Combined CBD + THC

Combined CBD + THC

CBD did not alter the effects of

THC standing steadiness, hand-

eye coordination, manual

ation, heart rate, and

ormance on a delayed

followed by

$0.025 \mathrm{mg} / \mathrm{kg}$; 
smoked

Placebo

\begin{tabular}{|c|c|c|c|c|c|c|c|}
\hline $\begin{array}{l}\text { Englund et } \\
\text { al. }(2013)^{\mathrm{b}} \text {, } \\
\text { United } \\
\text { Kingdom }\end{array}$ & $\begin{array}{l}\text { To investigate whether } \\
\text { pre-treatment with } \\
\text { CBD would attenuate } \\
\text { positive psychotic } \\
\text { symptoms and } \\
\text { cognitive impairment } \\
\text { following THC. }\end{array}$ & $\begin{array}{l}48 \text { healthy volunteers } \\
\text { ( } 21 \text { women; } 27 \text { men) } 21-50 \\
\text { years, with self-reported } \\
\text { cannabis use at least once; } \\
\text { mean lifetime cannabis use: } \\
119-137 \text { times. Failure of } \\
\text { cannulation prevented the } \\
\text { administration of THC in } \\
\text { three participants. A urine } \\
\text { drug screen was carried out. } \\
\text { No alcohol } 24 \text { hrs or drugs } \\
\text { one week before testing. }\end{array}$ & $\begin{array}{l}\text { Placebo- } \\
\text { controlled, double- } \\
\text { blind, parallel } \\
\text { study across two } \\
\text { treatment } \\
\text { conditions. } 26 \\
\text { received placebo } \\
\text { and 22 CBD. } \\
\text { Randomly } \\
\text { allocated, } \\
\text { counterbalanced. }\end{array}$ & $\begin{array}{l}\text { Pre-treatment } \\
\text { (T-210 mins) } \\
\text { oral CBD } 600 \\
\text { mg followed by } \\
\text { intravenous } \\
\text { THC } 1.5 \mathrm{mg} \text {; } \\
\text { pre-treatment } \\
\text { (T-210 mins) } \\
\text { oral Placebo } \\
\text { followed by } \\
\text { intravenous } \\
\text { THC } 1.5 \mathrm{mg}\end{array}$ & $\begin{array}{l}\text { Digit span forward } \\
\text { and backward, } \\
\text { HVLT-R, MCCB, } \\
\text { NAB mazes PANSS, } \\
\text { plasma blood } \\
\text { concentration, SSPS, } \\
\text { symbol coding, } \\
\text { UMACL. }\end{array}$ & $\begin{array}{l}\text { Clinically significant increase } \\
\text { in positive symptoms following } \\
\text { THC were more common in the } \\
\text { group pre-treated with placebo } \\
\text { compared with the group pre- } \\
\text { treated with CBD } \downarrow \\
\text { Post-THC paranoia was lower } \\
\text { in the CBD group } \downarrow \\
\text { CBD inhibited the effects of } \\
\text { THC on episodic memory } \downarrow \\
\text { No difference in plasma } \\
\text { concentrations between groups } \\
=\end{array}$ & Low \\
\hline $\begin{array}{l}\text { Guy and } \\
\text { Robson } \\
\text { (2003), } \\
\text { United } \\
\text { Kingdom }\end{array}$ & $\begin{array}{l}\text { To assess the } \\
\text { pharmacokinetic } \\
\text { profile, safety and } \\
\text { tolerability of the test } \\
\text { treatments. }\end{array}$ & $\begin{array}{l}24 \text { healthy volunteers (men) } \\
18-50 \text { years, with self- } \\
\text { reported cannabis use at } \\
\text { least once. A urine drug } \\
\text { screen was carried out pre- } \\
\text { dose, follow-up drug } \\
\text { screens. No cannabis } 30 \\
\text { days before testing; no } \\
\text { alcohol or caffeine } 48 \mathrm{hr} \\
\text { before testing. }\end{array}$ & $\begin{array}{l}\text { Placebo- } \\
\text { controlled, double- } \\
\text { blind, crossover } \\
\text { study across three } \\
\text { treatment } \\
\text { conditions. } \\
\text { Randomised to } \\
\text { treatment order } \\
\text { using a Williams } \\
\text { Square Design. }\end{array}$ & $\begin{array}{l}\text { Oromucosal } \\
\text { spray THC } 10 \\
\mathrm{mg}+\mathrm{CBD} \\
10 \mathrm{mg} ; \\
\text { oromucosal } \\
\text { spray THC } 10 \\
\text { mg; oromucosal } \\
\text { spray Placebo }\end{array}$ & $\begin{array}{l}\text { Blood samples, } \\
\text { clinical chemistry, } \\
\text { ECG recordings, } \\
\text { palatability, self- } \\
\text { rating of subjective } \\
\text { intoxicating effects, } \\
\text { urinalysis. }\end{array}$ & $\begin{array}{l}\text { Active treatments intoxication } \\
\text { scores were low, and effects not } \\
\text { related to plasma } \\
\text { concentrations } \\
\text { THC T Tax statistically } \\
\text { significantly later following } \\
\text { CBD+THC than THC alone } \downarrow \\
\text { It is possible that the presence } \\
\text { of CBD in the CBD+THC } \\
\text { formulation delays the } \\
\text { absorption of THC } \downarrow \\
\text { Wide inter- and intra-subject } \\
\text { variability }\end{array}$ & Low \\
\hline
\end{tabular}




\begin{tabular}{|c|c|c|c|c|c|c|c|}
\hline $\begin{array}{l}\text { Haney et al. } \\
(2016), \\
\text { United } \\
\text { States }\end{array}$ & $\begin{array}{l}\text { To assess the } \\
\text { influence of oral CBD } \\
\text { on the reinforcing, } \\
\text { subjective, cognitive, } \\
\text { and physiological } \\
\text { effects of smoked } \\
\text { THC. }\end{array}$ & $\begin{array}{l}31 \text { heathy volunteers ( } 14 \\
\text { women; } \\
17 \text { men) } 18-50 \text { years, with } \\
\text { self-reported current } \\
\text { cannabis use; an additional } \\
19 \text { participants withdrew or } \\
\text { were excluded. Urine drug } \\
\text { screen, breathalyser and } \\
\text { carbon monoxide test. No } \\
\text { cannabis, alcohol, cannabis } \\
\text { or tobacco } 12 \mathrm{hr} \text { before } \\
\text { testing. }\end{array}$ & $\begin{array}{l}\text { Placebo-controlled } \\
\text { double-blind, } \\
\text { crossover study } \\
\text { across eight } \\
\text { treatment } \\
\text { conditions. } \\
\text { Randomised to } \\
\text { treatment order. }\end{array}$ & $\begin{array}{l}\text { Pre-treatment } \\
\text { (T-90mins) oral } \\
\text { CBD 200, 400, } \\
800 \mathrm{mg} \\
\text { followed by } \\
\text { smoked THC } \\
42 \mathrm{mg} \text {; pre- } \\
\text { treatment (T- } \\
\text { 90mins) oral } \\
\text { Placebo } \\
\text { followed by } \\
\text { smoked THC } \\
42 \mathrm{mg}\end{array}$ & $\begin{array}{l}\text { Blood pressure, } \\
\text { CPT, heart rate, } \\
\text { DSST, self-rating of } \\
\text { mood and subjective } \\
\text { intoxicating effects. }\end{array}$ & $\begin{array}{l}\text { CBD did not significantly alter } \\
\text { the increase subjective } \\
\text { intoxication effects or increased } \\
\text { estimates of the street value of } \\
\text { the cannabis smoked associated } \\
\text { with THC alone = } \\
\text { CBD did not significantly } \\
\text { influence the significant } \\
\text { increase in peak heart rate } \\
\text { following THC = }\end{array}$ & Low \\
\hline $\begin{array}{l}\text { Hindocha et } \\
\text { al. (2015); } \\
\text { Morgan et } \\
\text { al. (2018); } \\
\text { Wall et al. } \\
\text { (2019) } \\
\text { United } \\
\text { Kingdom }\end{array}$ & $\begin{array}{l}\text { To determine the } \\
\text { effects of THC and } \\
\text { CBD, both alone and } \\
\text { in combination on } \\
\text { emotional facial affect } \\
\text { recognition subjective } \\
\text { effects and memory } \\
\text { function. Secondary } \\
\text { analyses: To } \\
\text { investigate psychosis- } \\
\text { like effects. }\end{array}$ & $\begin{array}{l}48 \text { heathy volunteers (14 } \\
\text { women; } 34 \text { men) 18-26 } \\
\text { tyears, with either daily (24) } \\
\text { or recreational (24) self- } \\
\text { reported cannabis use. No } \\
\text { alcohol or illicit drug use } \\
\text { 24hr before testing. }\end{array}$ & $\begin{array}{l}\text { Placebo- } \\
\text { controlled, double- } \\
\text { blind, } \\
\text { crossover study } \\
\text { across four } \\
\text { treatment } \\
\text { conditions. } \\
\text { Analysed by four } \\
\text { groups: high vs } \\
\text { low SPQ score; } \\
\text { and frequency of } \\
\text { cannabis use: daily } \\
\text { vs recreational. } \\
\text { Randomised using } \\
\text { a Latin squares } \\
\text { design. }\end{array}$ & $\begin{array}{l} \\
\text { Vaporised THC } \\
8 \mathrm{mg}+\text { CBD } 16 \\
\text { mg; vaporised } \\
\text { THC } 8 \mathrm{mg} \text {; } \\
\text { vaporised } \\
\text { Placebo }\end{array}$ & $\begin{array}{l}\text { BSS, dot-probe task, } \\
\text { emotional } \\
\text { processing task, } \\
\text { genotyping, MCQ, } \\
\text { N-back, prose recall, } \\
\text { self-rating of } \\
\text { subjective } \\
\text { intoxicating effects, } \\
\text { trail making task. }\end{array}$ & $\begin{array}{l}\text { Primary outcomes: CBD } \\
\text { reduced the impairment of } \\
\text { recognition of ambiguous faces } \\
\text { of } 40 \% \text { intensity associated } \\
\text { with THC } \downarrow \\
\text { THC alone and combined } \\
\text { THC+CBD equally increased } \\
\text { feelings of being 'stoned' = } \\
\text { Secondary outcomes: Both } \\
\text { THC alone and in combination } \\
\text { with CBD increased negative } \\
\text { symptoms on the BPRS, } \\
\text { perceptual distortions \& } \\
\text { cognitive disorganisation on the } \\
\text { PSI = } \\
\text { The influence of CBD on THC } \\
\text { may differ according to } \\
\text { variation in endocannabinoid } \\
\text { system genetics. }\end{array}$ & Low \\
\hline
\end{tabular}


The onset of effects measured

by a narrative summary of

Hollister Crossover study

and

Gillespie

(1975),

United

States
15 healthy volunteers (men) across three

To test if CBD and 18+ years, with self-

$\mathrm{CDN}$ interact with the reported cannabis use at

treatment

effects of THC.

reported. conditions.

Oral THC 20

$\mathrm{mg}+\mathrm{CBD} 40$

$\mathrm{mg}$; oral THC

$20 \mathrm{mg}$; ora

Latin Squares Placebo design.
ARCI, conjunctival

hyperaemia, drug

intensity rating,

of subjective

across treatments $=$

urinalysis. pulse rate, self-rating was slightly slower $\downarrow$

subjective effects of THC+

CBD compared to THC alone

Metabolites in urine samples were more numerous following the THC + CBD combination than after THC alone $\uparrow$

\section{Pre-treatmen}

(T-480, -300, -

\begin{tabular}{|c|c|c|c|c|c|c|c|}
\hline $\begin{array}{l}\text { Hunt et al. } \\
\text { (1981), } \\
\text { United } \\
\text { States }\end{array}$ & $\begin{array}{l}\text { To investigate the } \\
\text { effect of CBD on THC } \\
\text { pharmacokinetics. }\end{array}$ & $\begin{array}{l}\text { Four healthy volunteers } \\
\text { (men) 22-30 years, with } \\
\text { self-reported cannabis use } \\
\text { 4-10 times; and cigarettes } \\
\text { per week for an average of } \\
8.3 \text { years before the study. } \\
\text { Participants remained on- } \\
\text { site to ensure abstinence } \\
\text { from drugs and medication } \\
\text { 48hrs before testing. }\end{array}$ & $\begin{array}{l}\text { Placebo- } \\
\text { controlled, double- } \\
\text { blind, crossover } \\
\text { study across two } \\
\text { treatment } \\
\text { conditions. } \\
\text { Participants } \\
\text { counterbalanced to } \\
\text { receive treatments } \\
\text { in a different order. }\end{array}$ & $\begin{array}{l}120 \text { mins) oral } \\
\text { CBD } 500 \mathrm{mg} \\
\text { followed by } \\
\text { intravenous } \\
\text { THC } 2 \mathrm{mg} \text {; pre- } \\
\text { treatment (T- } \\
480,-300,-120 \\
\text { mins) oral } \\
\text { Placebo } \\
\text { followed by } \\
\text { intravenous } \\
\text { THC } 2 \text { mg }\end{array}$ & $\begin{array}{l}\text { Blood sample, } \\
\text { fingertip } \\
\text { temperature, heart } \\
\text { rate } \\
\text { pharmacokinetics, } \\
\text { self-rating of } \\
\text { subjective } \\
\text { intoxicating effects, } \\
\text { urinalysis. }\end{array}$ & $\begin{array}{l}\text { Pre-treatment with CBD did not } \\
\text { alter the pharmacokinetic or } \\
\text { pharmacodynamic effects of } \\
\text { THC = } \\
\text { There may be minimal effect on } \\
\text { the formation and excretion of } \\
\text { metabolites. Total (metabolic) } \\
\text { blood clearance of THC } \\
17 \mathrm{ml} / \mathrm{min} / \mathrm{kg} \text { without CBD and } \\
20.9 \mathrm{ml} / \mathrm{min} / \mathrm{kg} \text { with CBD } \uparrow\end{array}$ & $\begin{array}{l}\text { Some } \\
\text { concerns }\end{array}$ \\
\hline $\begin{array}{l}\text { Karniol et } \\
\text { al. }(1974)^{\mathrm{c}} \text {, } \\
\text { Brazil }\end{array}$ & $\begin{array}{l}\text { To investigate whether } \\
\text { THC + CBD would } \\
\text { induce less 'high' or } \\
\text { psychosis-like effects } \\
\text { that would be } \\
\text { expected from THC } \\
\text { alone. }\end{array}$ & $\begin{array}{l}\text { ro recruited ( } 10 \text { excluded } \\
\text { before assignment to a } \\
\text { group) healthy volunteers } \\
\text { (men), } 21-34 \text { years, } 22 \text { with } \\
\text { self-reported cannabis use } \\
\text { at least once; } 18 \text { had never } \\
\text { used cannabis. No alcohol } \\
24 \mathrm{hr} \text { before testing. }\end{array}$ & $\begin{array}{l}\text { Placebo- } \\
\text { controlled, double- } \\
\text { blind, parallel } \\
\text { study across eight } \\
\text { treatment } \\
\text { conditions. Groups } \\
\text { balanced for age } \\
\text { and weight. }\end{array}$ & $\begin{array}{l}\text { Oral THC } 30+ \\
\text { CBD 15, } 30 \text { or } \\
60 \mathrm{mg} \text {; oral } \\
\text { THC } 30 \mathrm{mg} \text {; } \\
\text { oral Placebo }\end{array}$ & $\begin{array}{l}\text { Pulse rate, self- } \\
\text { rating of subjective } \\
\text { intoxicating effects, } \\
\text { time production task. }\end{array}$ & $\begin{array}{l}\text { CBD seemed to block the } \\
\text { anxiety-provoking effects of } \\
\text { THC } \downarrow \\
\text { CBD was found to attenuate } \\
\text { several effects of THC, such as } \\
\text { pulse rate acceleration, time } \\
\text { production impairment and } \\
\text { psychological disturbances } \downarrow\end{array}$ & $\begin{array}{l}\text { Some } \\
\text { concerns }\end{array}$ \\
\hline
\end{tabular}


To examine acute

T. P.

Freeman,

Pope, et al.

(2018);

Lawn et

(2016);

Wall et al.

(2019),

United

Kingdom

to reward and

emotion, and

subjective ratings effects of THC + CBD 17 healthy volunteers (nine

and THC alone on women; eight men) 18-70 Placebo-

effort-related decision-years, with self-reported

making. Secondary cannabis use $(\geq 4$ times in

aims: Investigate the last year, $\leq 3$

response to music in times/week; one participant

brain regions sensitive excluded in T.P. Freeman et

al. 2018. Urine drug screen

at each session, no alcohol

following THC and

each testing session.

test if offset by CBD. controlled, double-

blind, crossover

study across four treatment

conditions.

Randomised to

treatment order

using a Latin

squares design.
Primary outcomes: CBD did

not affect reduced motivation

for high-effort choice

associated with THC to make a

to earn rewards $=$

CBD altered increased

sensitivity to monetary value

Blood pressure,

Vaporised THC EEfRT, fMRI, he

$8 \mathrm{mg}+$ CBD 10 rate, SDS Snailton pleasure Secondary outcomes: Higher

mg; vaporised Hamilon pleasure

THC 8 mg;

vaporised

scale, self-rating of

subjective

intoxicating effects,

temporal

experiences of

pleasure scale.

enhanced sound perception

after THC+CBD than THC $\downarrow$ Low

THC alone dampened the

response to music in several

reward and emotion brain

regions, THC+CBD did not

differ from placebo and showed

greater connectivity $\downarrow$

THC alone reduced

connectivity within the salience network when compared to

$\mathrm{THC}+\mathrm{CBD} \downarrow$

\begin{tabular}{|c|c|c|c|c|c|c|c|}
\hline $\begin{array}{l}\text { Juckel et al. } \\
(2007) ; \\
\text { Nadulski et } \\
\text { al. }(2005) ; \\
\text { Roser et al. } \\
(2009) \text {; } \\
\text { Roser et al. } \\
(2008) ; \\
\text { (Stadelmann } \\
\text { et al., } \\
\text { 2011), } \\
\text { Germany }\end{array}$ & $\begin{array}{l}\text { To investigate the } \\
\text { effects of CBD on the } \\
\text { pharmacokinetics of } \\
\text { THC. Secondary } \\
\text { analyses: investigate } \\
\text { psychotic states and } \\
\text { schizophrenic } \\
\text { conditions; acute } \\
\text { effects of } \\
\text { cannabinoids on P300 } \\
\text { amplitude; } \\
\text { psychomotor } \\
\text { performance by using }\end{array}$ & $\begin{array}{l}28 \text { healthy volunteers } \\
\text { recruited }{ }^{\text {a }}, 20-24 \text { included } \\
\text { depending on the analysis } \\
\text { (up to } 12 \text { women; } 12 \text { men). } \\
\text { Three participants had a } \\
\text { panic attack. For others } \\
\text { there were technical issues } \\
\text { with ERP recording or } \\
\text { quality of recording. } \\
\text { Participants were } 18-45 \\
\text { years with self-reported } \\
\text { cannabis use at least once, } \\
\text { but never regular use. Urine }\end{array}$ & $\begin{array}{l}\text { Placebo- } \\
\text { controlled, double- } \\
\text { blind, crossover } \\
\text { study across three } \\
\text { treatment } \\
\text { conditions. } \\
\text { Randomised to } \\
\text { treatment order. }\end{array}$ & $\begin{array}{l}\text { Oral THC } 10 \\
\text { mg + CBD } 5.4 \\
\text { mg; oral THC } \\
10 \text { mg; oral } \\
\text { Placebo }\end{array}$ & $\begin{array}{l}\text { AIR-scales, auditory } \\
\text { evoked MMN } \\
\text { recorded via ERP } \\
\text { recording, blood } \\
\text { plasma levels, DNA } \\
\text { genotyping, eye- } \\
\text { movement finger } \\
\text { tapping asymmetry, } \\
\text { inter-manual } \\
\text { coordination. }\end{array}$ & $\begin{array}{l}\text { Primary outcomes: CBD } \\
\text { inhibits the metabolic } \\
\text { hydroxylation of THC; but the } \\
\text { effect is small } \downarrow \\
\text { Secondary outcomes: Greater } \\
\text { auditory evoked MMN } \\
\text { amplitude following } \\
\text { THC+CBD but not THC alone } \\
\downarrow \\
\text { No difference in P300 } \\
\text { amplitudes under THC and } \\
\text { THC+CBD }=\end{array}$ & $\begin{array}{l}\text { Some } \\
\text { concerns }\end{array}$ \\
\hline
\end{tabular}


a finger tapping test screen for illicit drugs

series; if (AAT)n before each testing session,

polymorphism self-report no cannabis one

differentially month; no alcohol, caffeine,

modulates

$48 \mathrm{hrs}$ before; no nicotine

cannabinoid effect on $12 \mathrm{hrs}$

P300 generation

during an auditory

choice reaction task.
THC+CBD but not THC alone

reduced right-hand tapping

frequencies $\uparrow$

$>10 />10$ genotypes showed a

decrease of P300 amplitude and

prolongation of P300 latency

under THC alone but not

$\mathrm{THC}+\mathrm{CBD} \downarrow$

Correlation between AAT

repeats and P300 variables for

THC alone.

\section{Blood plasma levels,}

choice reaction time

delayed and

THC alone and in combination

immediate word with CBD increased sleepiness

Eight healthy volunteers Placebo-

Nicholson To assess the effects (four women; four men) 18

et al. of cannabis extracts on 35 years, with self-reported blind, crossover

(2004) nocturnal sleep, early cannabis use at least once, stind, crossover

Oromucosal

recall, digit symbol,

30minutes after waking,

spray THC 15 heart rate, letter and negatively affected mood =

$\mathrm{mg}+\mathrm{CBD} 15$ digit memory recall, THC+CBD but not THC alone

$\mathrm{mg}$; oromucosal multi-attribute task decreased stage 3 sleep and

spray THC 15 battery, pulse rate, increased time spent awake $\uparrow$

treatment

conditions.

$\mathrm{mg}$; oromucosal self-rating of

Randomisation not spray Placebo subjective

THC decreased latencies to

early morning sleep and

intoxicating effects, impaired episodic memory, not

sleepiness, sustained present with THC + CBD $\downarrow$ attention, sleep

latency.

\begin{tabular}{|c|c|c|c|c|c|c|c|}
\hline $\begin{array}{l}\text { Zuardi et al. } \\
\text { (1982), } \\
\text { Brazil }\end{array}$ & $\begin{array}{l}\text { To investigate whether } \\
\text { CBD diminished the } \\
\text { anxiety produced by } \\
\text { THC in healthy } \\
\text { volunteers, and to } \\
\text { verify whether this } \\
\text { effect occurs through }\end{array}$ & $\begin{array}{l}\text { r Eight healthy volunteers } \\
\text { (two women; six men) } 20- \\
38 \text { years, with self-reported } \\
\text { cannabis use at least once, } \\
\text { three had never used } \\
\text { a cannabis. } 15 \text { days }\end{array}$ & $\begin{array}{l}\text { Placebo- } \\
\text { controlled, double- } \\
\text { blind, crossover } \\
\text { across six } \\
\text { treatment } \\
\text { conditions. } \\
\text { Participants }\end{array}$ & $\begin{array}{l}\text { Oral THC } 0.5 \\
\mathrm{mg} / \mathrm{kg}+\mathrm{CBD} 1 \\
\mathrm{mg} / \mathrm{kg} ; \text { oral } \\
\mathrm{THC} 0.5 \\
\mathrm{mg} / \mathrm{kg} ; \text { oral } \\
\text { Placebo }\end{array}$ & $\begin{array}{l}\text { ARCI-Ma, } \\
\text { interviews of } \\
\text { subjective effects, } \\
\text { pulse rate, Scale of } \\
\text { Bodily Symptoms, } \\
\text { self-rating of } \\
\text { subjective }\end{array}$ & $\begin{array}{l}\text { THC increased pulse rate, CBD } \\
\text { did not alter this effect = } \\
\text { When combined with CBD } \\
\text { blocks the anxiety provoked by } \\
\text { THC } \downarrow \\
\text { CBD blocks subjective effects } \\
\text { measured on the ARCI-Ma } \downarrow\end{array}$ & $\begin{array}{l}\text { Some } \\
\text { concerns }\end{array}$ \\
\hline
\end{tabular}


general block of the action of THC or a specific effect on the abstinence of cannabis

received before testing.

treatments in a

anxiety.

intoxicating effects;

STAI; self-rating of

subjective

intoxicating effects.

Notes. effect: $\uparrow$ increases effects of THC; $\downarrow$ decreases effects of THC, = no difference of effect; *interventions - only interventions relevant to the review are reported; Risk of bias tool: Cochrane's risk of bias tool (either for parallel/crossover study design); Where multiple publications for single study first publication reported as primary outcomes, all subsequent as secondary outcomes. AIR-scale: visual Analogue Intoxication Rating Scales; ARCI-Ma: Addiction Research Center Inventory for Marihuana Effects; BSS: Bodily Symptoms Scale; CBD: cannabinol; CMI: Cornell Medical Index; CPT Continuous Performance Task; DAF: Delayed Auditory Feedback; DAT: Divided attention task; DSST: Digit Symbol Substitution Task; DSST: Digit Symbol Substitution Task; ECG: electrocardiogram; EEfRT: Effort expenditure for rewards task; ERP: event-related brain potential; fMRI: functional magnetic resonance imaging; hr: hours; HVLT-R: Hopkins Verbal Learning TaskRevised; iv: intravenous; MCCB: MATRICS Consensus Cognitive Battery; MCQ: Marijuana Craving Questionnaire; MMN: mismatch negativity; n: total number of participants; NAB: Neuropsychological Assessment Battery; PANSS: Positive and Negative Syndrome Scale; PASAT: Paced Auditory Serial Addition Task; SDS: Severity of Dependence Scale; SPSS The State Social Paranoia Scale, STAI: Spielberger's State-Trait Anxiety Inventory; THC: delta-9-tetrahydrocannabinol; UMACL: University of Wales Mood Adjective Checklist; VDA: Vienna Determination Apparatus; a. 166 divided into 16 groups; b. placebo n= 22 CBD n=26, c. 8 groups of 5; d. not all participants completed all measures in this study 2 men, and 2 women did not complete ERP recording due to technical issues and three women had a panic attack. Therefore Roser et al. (2008) and Stadlemann et al. (2011) included 20 participants; Nadulski et al. (2005) and Roser et al. (2009) included 24 participants; 


\subsection{Participants}

All studies included healthy volunteers, and all except two (Karniol et al., 1974; Zuardi et al., 1982) included only participants with previous experience of cannabis use.

\subsection{Treatment characteristics}

Table 1 shows the treatment characteristics of each study. There was considerable variability in the doses of both $\mathrm{THC}$ and $\mathrm{CBD}$, and in the ratio of THC to CBD. There was also heterogeneity in the route of administration used across treatments and studies. For CBD administration, eight studies used oral doses $(5.4 \mathrm{mg}-800 \mathrm{mg})$, one intravenous (5mg), two vaporised (4mg-16mg), two smoked $(0.150-0.320 \mathrm{mg} / \mathrm{kg})$, and two used an oromucosal spray (10mg-15mg). For THC administration, six studies used oral (10mg-40mg), three intravenous $(1.25 \mathrm{mg}-2 \mathrm{mg})$, three smoked $(42 \mathrm{mg}$ or 0.215 $0.025 \mathrm{mg} / \mathrm{kg}$ ), two vaporised (8mg), and two used an oromucosal spray (10mg-15mg). Five studies used a design where a dose of CBD or placebo was administered as a pretreatment before THC administration. These were administered either orally (200$1500 \mathrm{mg}) 480$ to 90 minutes before, via a smoked joint $(0.150 \mathrm{mg} / \mathrm{kg}), 30$ minutes ahead, or intravenously immediately before THC. Where studies used a design that included a pre-treatment, they did not include a pure placebo condition and used baseline measurements which were administered before any drug. The remaining studies all used a design which included a treatment condition where participants received placebo only. 


\subsection{Risk of bias within studies}

Only ten studies were found to be at low risk of bias (Arkell et al., 2019; Bhattacharyya et al., 2010; Dalton et al., 1976; Englund et al., 2013; Guy \& Robson, 2003; Haney et al., 2016; Hindocha et al., 2015; Lawn et al., 2016; Nicholson et al., 2004); some concerns were found for six studies (Bird et al., 1980; Hollister \& Gillespie, 1975; Hunt et al., 1981; Karniol et al., 1974; Nadulski et al., 2005; Zuardi et al., 1982); none were evaluated as high risk of bias. A table summarising the findings from the risk of bias assessment can be found in Appendix G.

\subsection{Risk of bias across studies}

Indicators for risk of bias across studies were assessed (Boutron et al., 2019). Overall this area of research has low risk of publication bias as many studies report a mixture of significant and non-significant findings. This review only included studies published in the English language and therefore may have missed important findings reported in different languages. Some studies were funded by an industry sponsor and therefore present a potential conflict of interest (Guy \& Robson, 2003; Nicholson et al., 2004). One possible bias across studies is recreational use of cannabis external to the study, which may have resulted in residual drug effects, and could have affected participants' performance. Another bias across studies may have been that individuals were able to identify the placebo condition over active treatment conditions, although this would not be expected to be a concern for the comparison between the THC versus THC+CBD conditions. 


\subsection{Synthesis of results}

Table 1 summarises the findings of comparisons between THC with and without CBD for the studies included in this review. A narrative synthesis of the findings from the review was conducted because the heterogeneity of outcomes used across studies precluded meta-analysis.

\subsubsection{Pharmacokinetic effects}

Pharmacokinetics were assessed in eight studies. Overall, typically studies reported that CBD did not significantly alter the pharmacokinetic profile of THC. Although three studies suggested that CBD may have a small effect on the metabolism of THC, findings were inconsistent. Three out of the eight studies were rated as having some concerns in at least one domain of the risk of bias assessment (Hollister \& Gillespie, 1975; Hunt et al., 1981; Nadulski et al., 2005).

In a study of 14 participants, the combination of vaporised THC $(13.75 \mathrm{mg})$ and vaporised CBD (13.75mg) was associated with significantly increased peak plasma concentrations of THC when compared to vaporised THC (13.75mg) alone (Arkell et al., 2019). Although not statistically significant, the area under the curve (0-3 hours) for plasma THC was higher for the combined THC+CBD treatment than THC alone. Nadulski et al. (2005) showed that co-administration of oral CBD $(5.4 \mathrm{mg})$ altered the metabolism of oral THC (10mg) by partially inhibiting the cytochrome P450 enzymes, which hydroxylate THC to its metabolite 11-hydroxy-THC. The authors suggest this may lead to a slight rise and earlier peak in THC concentration when THC is combined with CBD. However, in this study of 24 participants there was wide inter-participant variability. In a later publication of the same study, Roser et al. (2009) report 
significantly higher levels of 11-OH-THC and THC-COOH in women compared to men following THC with CBD, but not following THC alone. In a study of 24 participants, Guy and Robson (2003) found the time taken to reach the maximum plasma concentration for THC was significantly later following oromucosal spray of THC (10mg) and CBD (10mg) combined when compared to oromucosal spray of THC (10mg) alone. The authors concluded that CBD might delay the absorption of THC. However, this study also reported wide inter- and intra-participant variability in pharmacokinetic parameters. There were no other significant differences in the pharmacokinetic profiles between the two test treatments.

In a study of only four participants, Hunt et al. (1981) concluded that pre-treatment with three doses of oral CBD at eight, six and two hours (total dose 1500mg) before intravenous THC (2mg) had no significant effect on the pharmacokinetics of THC when compared to pre-treatment with placebo. The authors report, however, that there may be a "real but slight" effect of CBD on the metabolism of THC, where total (metabolic) blood clearance of THC averaged $17 \mathrm{ml} / \mathrm{min} / \mathrm{kg}$ without CBD and 20.9ml/min/kg with CBD. In a study of 15 participants, Hollister and Gillespie (1975) found that compared to oral THC (20mg) administered alone, when combined with oral CBD (40mg) THC was associated with increased concentrations of THC metabolites in urine. However, they attributed this to the additional presence of CBD rather than a change in the metabolism of THC.

A small crossover study ( $\mathrm{n}=6)$ found that pre-treatment with intravenous CBD (5mg) did not influence blood levels (area under the curve from 0 to 120 minutes) of 
THC following intravenous THC (1.25mg) when compared to placebo (Bhattacharyya et al., 2010). Similarly, a parallel group study $(n=36)$ found no significant difference in plasma concentration of THC following pre-treatment with oral CBD (600mg) or placebo (Englund et al., 2013). Nicholson et al. (2004) reported plasma concentrations for THC, OH-THC and COOH-THC but did not report comparisons between the treatment groups.

\subsubsection{Pharmacodynamic effects}

\subsubsection{Pulse rate}

Of the ten studies that reported outcomes for the effects of cannabinoids on pulse rate, the risk of bias assessment found some methodological concerns for four studies (Bird et al., 1980; Hollister \& Gillespie, 1975; Karniol et al., 1974; Zuardi et al., 1982). Eight studies found that both THC alone and the combination of THC and CBD increased pulse rate when compared to baseline measurements or placebo, but there was no significant difference between the THC alone and the combination of the two drugs (Bird et al., 1980; Dalton et al., 1976; T. P. Freeman, Pope, et al., 2018; Guy \& Robson, 2003; Haney et al., 2016; Hollister \& Gillespie, 1975; Zuardi et al., 1982). Another study, which investigated the effect of THC and CBD on sleep in just eight participants, found no differences in pulse rate between treatments (sublingual drops of a placebo, THC 10mg, THC 10mg + CBD 10mg) during the 30 minutes following drug administration (Nicholson et al., 2004). However, on waking the next morning both the THC alone and in combination with CBD were associated with postural systolic hypotension, with compensatory increases in supine and erect pulse rate when compared to placebo. 
In contrast, Karniol et al. (1974) reported results from a very small parallel group study ( $\mathrm{n}=40 ; \mathrm{n}=5$ per group) where oral THC (30mg) alone significantly increased pulse rate, but when THC was combined with low dose oral CBD (15mg), it seemed to increase pulse rate further. However, when THC (30mg) was combined with higher doses of oral CBD (30mg or $60 \mathrm{mg}$ ), the combination seemed to have the opposite effect, reducing the acceleration of pulse rate associated with THC alone.

\subsubsection{Blood pressure}

Three studies reported outcomes for blood pressure. There were no concerns about the risk of bias. Findings of two studies suggest that CBD might alter the effect of THC on blood pressure. Guy and Robson (2003) reported no notable changes in diastolic blood pressure, however, three hours after drug administration the mean systolic blood pressure decreased by $10.3 \mathrm{mmHg}$ following $\mathrm{THC}$ (10mg) alone; by $4.4 \mathrm{mmHg}$ following sublingual THC (10mg) and CBD (10mg) condition; and $5.1 \mathrm{mmHg}$ during the placebo period. In a crossover study of 17 participants, T. P. Freeman, Pope, et al. (2018) reported increased systolic blood pressure following both THC (8mg) alone and the combination of THC (8mg) and CBD (10mg) when compared to placebo, whereas diastolic blood pressure increased after drug administration in the THC alone condition, but not following co-administration of THC and CBD. However, Haney et al. (2016) did not find significant differences in blood pressure across their different treatment groups $(n=31)$ in a study of pre-treatment (90mins) with either oral CBD $(200,400,800 \mathrm{mg})$ or placebo 90 minutes before smoking a joint of THC ( 42 mg).

\subsubsection{Subjective intoxicating effects}

There was much variation in the way studies measured subjective effects. Of the nine studies, most included visual analogue scales (VAS) where participants self-rated 
feelings of intoxication. Two studies presented some concern about the potential risk of bias (Bird et al., 1980; Zuardi et al., 1982). The evidence for CBD potentially reducing the acute subjective effects of THC comes from two small experimental studies. In Dalton et al.'s (1976) double-blind, crossover study ( $\mathrm{n}=15)$, smoked THC $(0.025 \mathrm{mg} / \mathrm{kg})$ alone was associated with an increase in feeling "high" and increased drug-related effects on a modified version of the Cornell Medical Index (CMI) symptoms (a list of symptoms self-rated for intensity on a 0 to 4 scale). CBD $(0.150 \mathrm{mg} / \mathrm{kg})$ significantly reduced the effects of THC. Similarly, Zuardi et al. (1982) found in a small double-blind crossover study $(\mathrm{n}=8)$, that oral THC $(0.5 \mathrm{mg} / \mathrm{kg})$ and CBD $(1 \mathrm{mg} / \mathrm{kg})$ combined reduced the increase in subjective feelings on the Addiction Research Center Inventory for marihuana effects (ARCI-Ma) associated with oral THC $(0.5 \mathrm{mg} / \mathrm{kg})$ alone. In contrast to these findings, seven studies found no evidence for CBD moderating the subjective intoxicating effects of THC (Arkell et al., 2019; Bird et al., 1980; Dalton et al., 1976; T. P. Freeman, Pope, et al., 2018; Haney et al., 2016; Hindocha et al., 2015; Roser et al., 2009).

\subsubsection{Anxiety}

Three studies, two of which have an unclear risk of bias (Karniol et al., 1974; Zuardi et al., 1982), reported outcomes for anxiety-related symptoms. The interaction of CBD on the anxiety-inducing effects of THC was first described by (Karniol et al., 1974) in a placebo-controlled, double-blind, parallel group study ( $n=40 ; n=5$ per group). The study used a specially developed scale (Appendix H) where subjective drug effects were graded (from 0 to 4 ) if the participant reported at least three symptoms listed in each grade (Karniol \& Carlini, 1973). The scale lists anxiety and psychosis-related items, for example, Grade 0 "nothing or slight anxiety", to Grade 4, "panic; intense 
sensation of being watched; impossibility to have coherent thoughts due to the rapid flow of ideas". Oral THC (30mg) induced Grade 4 effects in four out of five participants. However, when oral CBD (15mg, 30mg \& 60mg respectively) was combined with oral THC (30mg), 3 participants out of 15 experienced these effects. A dose-dependent effect was suggested, where no participants in the high CBD group met criteria for Grade 4. Zuardi et al.'s (1982) double-blind, crossover study ( $n=8)$ found that when oral CBD $(1 \mathrm{mg} / \mathrm{kg})$ was administered together with oral THC $(0.5 \mathrm{mg} / \mathrm{kg})$, it attenuated the significant increase in anxiety symptoms on the StateTrait Anxiety Inventory (STAI; Spielberger, 2010) associated with oral THC $(0.5 \mathrm{mg} / \mathrm{kg})$ alone. Arkell et al. (2019) reported in a study of 14 participants that vaporised THC (13.75 mg) both with and without vaporised CBD (13.75 mg) produced small but significant increases in ratings of anxiety and increases on the STAI 15 minutes after the drug was administered. However, only after vaporised THC (13.75 $\mathrm{mg}$ ) alone were these ratings still increased after an hour.

\subsubsection{Psychotomimetic and psychosis-like experiences}

Three studies included in this review investigated psychotomimetic and psychosis-like effects following the acute administration of THC. There were no concerns about potential bias. THC induced acute psychosis-like effects on the Positive and Negative Syndrome Scale (PANSS; Kay, Fiszbein, \& Opler, 1987), following intravenous THC (1.25mg) in three out of six participants (Bhattacharyya et al. 2010). This double-blind, pseudo-randomised, crossover study, found that pre-treatment with intravenous CBD (5mg), when compared to placebo, ameliorated the psychotomimetic effects of THC. Comparable effects were seen in Englund et al.'s (2013) randomised, double-blind, parallel study $(\mathrm{n}=48)$, which showed that although there was no statistical difference 
in the mean increase in scores on the PANSS after intravenous THC $(1.5 \mathrm{mg})$ following pre-treatment of placebo or oral CBD $(600 \mathrm{mg})$, fewer participants treated with CBD showed a clinically significant increase in positive symptoms ( $\geq 3$ points). Paranoia rated on the State Social Paranoia Scale (SSPS; D. Freeman et al., 2007) was lower in the group of participants who received pre-treatment with $\mathrm{CBD}$ when compared to those who received pre-treatment with placebo (Englund et al., 2013).

In contrast to these findings, however, Morgan et al. (2018) did not find any difference in acute psychotomimetic effects between two treatment conditions of vaporised THC (8mg) with or without vaporised CBD (16mg) respectively. The double-blind, placebo-controlled, crossover study $(n=48)$, showed that THC both alone and THC combined with CBD increased negative symptoms on the Brief Psychotic Rating Scale (BPRS; Overall \& Gorham, 1962) and total scores on the Psychotomimetic States Inventory (PSI; Mason, Morgan, Stefanovic, \& Curran, 2008). In particular scores on the perceptual and cognitive distortion subscales of the PSI were significantly higher than scores on placebo. The study did not find any differences in these effects based on frequency of cannabis use or trait schizotypal symptoms.

\subsubsection{Cognitive effects}

Seven studies reported outcomes related to cognitive tasks including those focused on memory, auditory processing, emotion and reward. Two studies presented some concerns on the risk of bias assessment (Juckel et al., 2007; Karniol et al., 1974; Roser et al., 2008; Stadelmann et al., 2011). 


\subsubsection{Episodic memory}

As previous studies have shown, THC alone had an acute detrimental effect on episodic memory in five studies (Dalton et al., 1976; Englund et al., 2013; Karniol et al., 1974; Morgan et al., 2018; Roser et al., 2008). Whether CBD is protective against these effects was less clear. Englund et al.'s (2013) study (n=48) showed that intravenous THC $(1.5 \mathrm{mg})$ alone impaired episodic memory on both the immediate and delayed recall tasks from the Hopkins Verbal Learning Task-Revised (HVLT-R; Brandt \& Benedict, 2001) when compared to baseline. Participants allocated to pretreatment with oral CBD $(600 \mathrm{mg})$ resulted in the same level of immediate recall following THC, but the impairment for delayed recall was ameliorated following CBD pre-treatment. In a cross over study $(n=48)$ Morgan et al. (2018) found that vaporised THC (8mg) both alone and when combined with vaporised CBD (16mg) showed the same level of impairment in episodic memory on prose recall in the story recall task from the Rivermead Behavioural Memory Test (RBMT; Wilson, Cockburn, Baddeley, \& Hiorns, 1989), when compared to placebo.

\subsubsection{2. $\quad$ Attention and working memory}

Morgan et al. (2018) found that vaporised THC ( $8 \mathrm{mg}$ ) both alone and when combined with vaporised CBD (16mg) impaired working memory on the N-back task (Kirchner, 1958). Karniol et al. (1974) showed that CBD reduced impairments on a time production task, which taps working memory processes (Lewis \& Miall, 2006). Participants were instructed to estimate 60 -second time intervals, and the study ( $\mathrm{n}=40$; $\mathrm{n}=5$ per group) demonstrated a phenomenon where administration of oral THC (30mg) alone led to an acceleration of the 'internal clock,' which was not present when oral THC (30mg) was co-administered with oral CBD (15mg, 30mg or 60mg). However, a parallel group study $(\mathrm{n}=48)$ by Englund et al. (2013) found that pre-treatment with 
oral CBD (600mg) did not seem to alter the impairing effects of intravenous THC (1.5mg) on working memory tasks, including digit span forward and backwards. Arkell et al. (2019) found that vaporised THC (13.75mg) alone, but not THC combined with vaporised CBD $(13.75 \mathrm{mg})$, induced impairments after 20 minutes on the Digit Symbol Substitution Test (McLeod, Griffiths, Bigelow, \& Yingling, 1982) compared to placebo in 14 participants. However, on the Divided Attention Task (Kleykamp, Griffiths, \& Mintzer, 2010) participants showed impaired performance 20 minutes following THC combined with CBD compared to THC alone or placebo.

\subsubsection{Semantic memory}

In a crossover study which included 48 participants, Morgan et al. (2018) found that verbal fluency was enhanced when vaporised THC (8mg) was combined with CBD (16mg), but there was no difference in verbal fluency performance between vaporised THC (8mg) alone and placebo.

\subsubsection{Auditory processing}

Juckel et al. (2007) aimed to investigate a component of auditory evoked brain potential (ERP) called mismatch negativity (MMN) amplitude which is an automatic, and pre-attentive event-related potential component associated with auditory processing and working memory. MMN processing is impaired in people who have a diagnosis of schizophrenia (Javitt, Doneshka, Grochowski, \& Ritter, 1995). The analysis $(n=22)$ showed that the combination of oral THC $(10 \mathrm{mg})$ and oral CBD (5.4mg), but not oral THC (10mg) alone, was associated with higher amplitudes at the central electrode compared to placebo. No deficits were found in the THC alone condition. The authors suggest the improvement in performance may occur due to the improved processing due to the effect of CBD on auditory information processing. In 
the same study Roser et al. (2008) analysed the amplitudes of auditory evoked P300 in the same sample, to investigate the effect of THC alone and in combination with CBD on electroencephalography (EEG) correlates of working memory and attentional functioning during a choice reaction time task. The analysis $(n=20)$ showed that THC alone, and when administered with CBD, significantly reduced P300 amplitude at midline frontal, central and partial electrodes and therefore CBD did not prevent the acute impairment of THC alone.

Stadelmann et al. (2011) later investigated whether the (AAT) $n$ polymorphism differentially modulates the effects of THC alone and THC combined with CBD on P300 generation during an auditory choice reaction task in the same sample $(n=20)$. There was a significant decrease of P300 amplitude and prolongation of P300 latency for both $>10$ genotypes in the THC alone condition, but not in the condition where THC and CBD were combined. There was a significant correlation between the number of AAT repeats and P300 variables for the THC condition. The authors suggest that this finding seems to indicate that the CNR1 gene may differentially alter sensitivity to the acute effects of cannabinoids on P300 generation.

Dalton et al. (1976) reported that smoked THC $(0.025 \mathrm{mg} / \mathrm{kg})$ decreased the frequency of verbal responses and increased errors on delayed auditory feedback (DAF) both alone and in combination with smoked CBD $(0.150 \mathrm{mg} / \mathrm{kg})$ in 16 participants. In a randomised, double-blind, crossover study $(\mathrm{n}=14)$ participants showed transient impairments following vaporised cannabis containing THC (13.75mg) both with and without CBD (13.75mg) on the Paced Auditory Serial Addition Task (Herrmann et al., 2015) when compared to placebo (Arkell et al., 2019). 


\subsubsection{Emotion and reward processing}

Two studies investigated the differential effects of THC and CBD during emotion and reward processing tasks. These studies presented a low risk of bias. Hindocha et al. (2015) demonstrated impairments in emotional processing on a task which assessed participants' emotional facial affect recognition (happy, sad, fearful, angry, disgust and surprise) following vaporised THC alone $(8 \mathrm{mg})$. The study $(\mathrm{n}=48)$ found that the impairment induced by vaporised THC (8mg) in emotional processing was blocked when it was combined with vaporised CBD (16mg).

In a similar study, Lawn et al. (2016) investigated the effects of cannabis containing different doses of cannabinoids on a task which taps effort-related decision making, the effort expenditure for rewards task (Treadway, Buckholtz, Schwartzman, Lambert, \& Zald, 2009). The study ( $\mathrm{n}=17)$ demonstrated that vaporised THC (8mg) increased sensitivity to probability and magnitude of reward (expected monetary value) relative to both placebo, and vaporised THC (8mg) administered with vaporised CBD (10mg). In a later publication from the same study (T. P. Freeman, Pope, et al., 2018), the researchers investigated the effects of cannabinoids while participants listened to music during functional magnetic resonance imaging (fMRI). Participants reported enhanced sound perception following co-administered THC and CBD when compared to THC alone. THC alone dampened the haemodynamic response to music in the bilateral auditory cortex, right amygdala, right hippocampus and parahippocampal gyrus, and right ventral striatum. However, when THC was combined with CBD, this effect was offset, and the response to music in these brain regions did not differ from placebo. Additionally, THC with CBD caused greater functional 
connectivity between the ventral striatum and auditory cortex during musical listening when compared to THC alone.

In the same study, Wall et al. (2019) investigated the effects of THC alone, THC in combination with CBD, and placebo during resting state fMRI. THC alone, and in combination with $\mathrm{CBD}$, reduced connectivity across the default mode network $(\mathrm{DMN})$. The DMN is a network of brain regions which are active in periods of wakeful rest and internally focused states and was defined in this study as brain regions showing positive connectivity with the posterior cingulate cortex (PCC). THC reduced connectivity within the DMN, and this effect correlated with increased subjective intoxicating effects (feeling "stoned" and "high"). THC and THC+CBD showed spatially dissociable effects on the salience network (SN) (Seeley et al., 2007) which toggles between internally focused states and external action and goal directed behaviours, defined in this study as brain regions showing positive connectivity with the anterior insula. Treatment effects across the whole SN indicated that THC alone showed an overall reduction in connectivity within the salience network when compared to THC co-administered with CBD.

\subsubsection{Psychomotor performance}

Four studies investigated the effects of cannabinoids on psychomotor performance. One study presented some concerns in a risk of bias assessment (Roser et al., 2009). Roser et al. (2009) investigated impairments in psychomotor performance which have been consistently associated with schizophrenia. In a randomised crossover study outcomes are reported on a finger tapping task in 24 healthy volunteers, following either oral THC (10mg) with CBD (5.4mg) combined, oral THC (10mg) alone, or oral placebo. On each of the three testing days participants completed a task which involved 
five 15-second, finger tapping 'sessions' (right- and left-hand tapping), with two sessions involving tapping while completing other tasks (humming or reading) and a final session with alternate tapping. The study reported that THC co-administered with $\mathrm{CBD}$, led to significantly reduced right-hand tapping frequencies compared to placebo in all but the alternate tapping sessions. There were no differences between placebo and the THC only condition. However, THC alone impaired left-handed frequencies in sessions without distraction tasks (two out of the five sessions); this impairment was associated with increased plasma concentrations of 11-OH-THC.

In a study investigating the effects of cannabinoids on a driving simulation task $(\mathrm{n}=14)$, both vaporised THC $(13.75 \mathrm{mg})$ with and without CBD $(13.75 \mathrm{mg})$ were found to increase lane weaving during a car following task (Arkell et al., 2019) when compared to placebo. Bird et al. (1980) did not find any evidence for oral CBD $(0.320 \mathrm{mg} / \mathrm{kg})$ moderating the effects of oral THC $(0.215 \mathrm{mg} / \mathrm{kg})$. This parallel study (16 groups, $\mathrm{n}=116$ ) combined several outcomes to create three factors. Visual, auditory, and complex reaction time were combined to create a reaction speed factor (factor 1), a standing steadiness factor included scores from eyes open and closed standing steadiness tasks (factor 2), and a third factor included the pursuit rotor and a psychomotor coordination and the Vienna determination apparatus (VDA) data (factor 3). THC alone impaired both standing steadiness and psychomotor coordination, but CBD did not moderate this effect. Dalton et al. (1976) also found in a crossover study $(\mathrm{n}=16)$ that both combined smoked THC $(0.025 \mathrm{mg} / \mathrm{kg})$ and CBD $(0.150 \mathrm{mg} / \mathrm{kg})$ and smoked THC $(0.025 \mathrm{mg} / \mathrm{kg})$ alone, when compared to placebo, reduced standing steadiness using a wobble board, hand-eye coordination on an attentive motor performance task, using a modified pursuit meter (Evans et al., 1973) and manual coordination and dexterity using a pegs test. 


\subsubsection{Sleep}

One study assessed the acute effects of THC, with and without CBD, on sleep. Nicholson et al. (2004) investigated the effect of oromucosal spray containing THC (15mg) and CBD (15mg) when compared to oromucosal spray containing THC (15mg) alone in eight participants. The study found that THC had sedative qualities, however, when THC was combined with CBD the spray increased the duration of wakefulness and stage 3 nocturnal sleep suggesting that $\mathrm{CBD}$ may have some activating properties. There were no differences in participants' ratings of sleep onset, duration or quality between treatments. However, THC alone was associated with increased sleepiness 30 minutes after waking, and decreased latencies to early morning sleep (Nicholson et al., 2004).

\subsubsection{Genetic vulnerability to the effects of cannabis}

Hindocha et al. (2019) analysed the effects of cannabinoids on addiction endophenotypes. The study $(\mathrm{n}=48)$ found that carriers of the CNR1 rs1049353 GG genotype reported decreased desire to smoke a joint after both vaporised THC (8mg), and vaporised THC (8mg) with vaporised CBD (16mg) when compared to placebo. Those with the A allele did not experience this reduction. There was no difference between THC with or without CBD. Those with the FAAH rs324420 genotype CC had lower attentional bias to appetitive cues following THC only when compared to A carriers. By contrast, $\mathrm{CC}$ and A carriers did differ on attentional bias following THC+CBD. These findings suggest that the ability of CBD to influence the effects of THC may differ according to variation in endocannabinoid system genetics. 


\section{Discussion}

In the first systematic review of how CBD influences the acute effects of THC, 23 eligible papers were identified reporting on 16 studies, including a total of 466 participants. All studies employed experimental designs with adequate control conditions, enabling comparison of the acute effects of THC with those of a matched dose of THC combined with CBD. The risk of bias across within and across studies was typically low.

When taken together, these results suggest that CBD may moderate some of the effects of THC, most commonly resulting in a reduction in its acute effects. However, the moderating effect of CBD was not consistent across all studies. There was some disparity in findings, and although the direction of associations was consistent in many studies associations did not reach statistical significance in all studies. There was also considerable heterogeneity in the interventions used across studies, including different routes of administration (oral, sublingual, smoked, vaporised, mixed with food, or made into a drink), doses of THC and CBD, and the ratio of THC to CBD. No consistent pattern of effects across these factors was found, consequently, it was not possible to determine whether there is a dose-response relationship influencing how CBD moderates the effects of THC. Several studies included an oral dose of CBD (5.4mg-800mg). As oral CBD has been shown to have low bioavailability (13-19\%; Mechoulam, Parker, \& Gallily, 2002) the findings from studies administering low doses of oral CBD should be interpreted with caution. Additionally, other factors may have influenced the effects of cannabinoids within studies and this may explain why several studies reported large variability in effects across participants. For example, cannabis use history, including the potency and frequency of previous cannabis used (Curran et al., 2002; Curran et al., 2018; D’Souza et al., 2008; Desrosiers, 2015), 
psychosis-proneness (Mason et al., 2009), gender (Cooper \& Haney, 2014; Klumpers et al., 2012) and genetic factors (Hindocha et al., 2019; Morgan, Freeman, Powell, \& Curran, 2016) can influence the acute effects of cannabinoids. The majority of studies did not assess for these issues which, alongside some very small sample sizes, may have contributed to variability in findings. It is recommended that future research should take these factors into account.

\subsection{Pharmacokinetic and pharmacodynamics effects}

The results obtained in this review show mixed findings and it is not clear how CBD influences the way THC is metabolised. While two studies showed that combining CBD with THC may lead to an increased peak plasma of THC (Arkell et al., 2019; Nadulski et al., 2005) another showed that when CBD was combined with THC the time to reach peak plasma concentrations was delayed (Guy \& Robson, 2003). Four studies showed non-significant findings when investigating the pharmacokinetic interactions between THC and CBD (Bhattacharyya et al., 2010; Englund et al., 2013; Hollister \& Gillespie, 1975; Hunt et al., 1981). In animal studies (Paton \& Pertwee, 1972), CBD has been found to inhibit the metabolism of THC and potentially other drugs when administered together. There was some indication that gender may contribute to differences in metabolism of cannabinoids, as Roser et al. (2009) reported higher levels of 11-OH-THC and THC-COOH in women compared to men following THC with CBD, but not following THC alone, which is consistent with some evidence showing that women experience more intense subjective effects than men (Cooper \& Haney, 2014; Haney et al., 2016). However, most studies in this review were small and did not report any significant differences in the pharmacokinetic profile of THC when it was combined with CBD. More extensive studies are needed to investigate 
these effects, particularly because there seems to be substantial variability between participants.

In terms of the pharmacodynamic profile, across studies, THC with and without CBD generally increased pulse rate. Outcomes on blood pressure were mixed, with two studies reporting that CBD reduced the effect of THC on diastolic and systolic blood pressure respectively. A recent study of a single dose of CBD (600mg) alone showed that it increases heart rate but reduces systolic blood pressure (Jadoon, Tan, \& O'Sullivan, 2017). These effects may be a consideration for prescribing clinicians and as well as recreational users of the drug.

\subsection{Subjective intoxication}

Participants predominantly experienced the subjective intoxicating effects of THC and THC combined with CBD similarly. These findings suggest that co-administration of THC and CBD may not reduce the desired effects of cannabis (Curran \& Morgan, 2014).

\subsection{Anxiety and psychosis-like experiences}

Three studies included in this review showed that significantly fewer participants experienced extreme feelings of anxiety and psychotic-like effects when THC was coadministered with $\mathrm{CBD}$. A recent study showed that the therapeutic properties of CBD within specific prefrontal brain regions in rats might be present only during pathologically aberrant states induced by THC (Szkudlarek et al., 2019). A mechanism whereby CBD only regulates $\mathrm{THC}$ when it has extreme effects may explain findings where CBD reduced clinically significant increases in psychosis-like effects, but not 
increases in these experiences overall (Englund et al., 2013). This may be an important consideration for future research, as previous studies may have excluded participants at risk of adverse effects of cannabis (such as acute psychotic symptoms) due to concerns about safety. However, the moderating effects of CBD may only be apparent in those who experience more severe responses to THC.

\subsection{Cognitive effects}

While some studies found that CBD was protective against the acute memoryimpairing effects of THC on tasks which tapped episodic memory and working memory, findings were not consistent. Schoeler and Bhattacharyya (2013) suggested that cannabis with higher doses of THC and lower CBD content produces robust acute memory deficits and that other factors may also contribute (e.g. tolerance, heavy early use). Regarding the specific components of memory that are affected, the studies included report outcomes for the number of items recalled correctly, consistent with an impairment in the encoding of episodic memories (Ballard, Gallo, \& de Wit, 2012, 2013). However, it is not clear whether these effects are also present for the retrieval of episodic memories which can be measured by comparing the recall of false intrusions (Doss, Weafer, Ruiz, Gallo, \& De Wit, 2018). Evidence suggests that THC impairs encoding but not retrieval of episodic memory (Ranganathan et al., 2017), but the specific effects of $\mathrm{CBD}$ on encoding versus retrieval are currently unclear. Collectively, studies included in the current review which investigated effects on memory included a wide range of doses and routes of administration of both THC and $\mathrm{CBD}$, and no clear pattern of results emerged. 
One study found that verbal fluency was enhanced when vaporised THC was combined with CBD but there was no difference in verbal fluency performance between vaporised THC alone and placebo (Morgan et al., 2018). However, a previous study has shown that oral THC alone can dose-dependently enhance verbal fluency (Curran et al., 2002) while another study found that vaporized cannabis impaired verbal fluency (Kowal et al., 2015). This suggests that the effects of THC on verbal fluency are inconsistent, and may be moderated by other factors in addition to CBD.

There was some evidence to suggest that $\mathrm{CBD}$ may influence the effects of THC on emotion and reward processing. When combined with THC, CBD attenuated impairments associated with THC (Hindocha et al., 2015; Lawn et al., 2016). These findings, however, come from only two studies. CBD did not reduce the impairments of THC across a range of psychomotor tasks (such as standing steadiness) in two studies (Bird et al., 1980; Dalton et al., 1976). One study found differences in finger tapping, where THC with CBD, but not THC alone, impaired performance on a task which is found to be related to impairments seen in schizophrenia (Roser et al., 2009).

\subsection{Genetics}

There was also evidence from two studies that genetic variants of the CNR1 gene may also influence the relationship between $\mathrm{CBD}$ and THC where the effects of the drugs alone and in combination depend on individual endocannabinoid system genetics (Hindocha et al., 2019; Stadelmann et al., 2011). Variations of the CNR1 gene may differentially alter sensitivity to the acute effects of cannabinoids on P300 generation (Stadelmann et al., 2011). Hindocha et al. (2019) found endocannabinoid system genetics may influence vulnerability to satiety, attentional bias towards appetitive cues 
and craving which suggests that these differences may influence markers of vulnerability to cannabis use disorders.

\subsection{The role of $\mathrm{CBD}$ in harm reduction}

Although some studies reported that CBD may reduce the potentially harmful effects of cannabis, evidence suggests that combining THC with CBD may not necessarily reduce the desired intoxicating effects of the drug. More research is needed to fully elucidate how CBD influences the effects of THC. This is a complex issue as CBD has multiple mechanisms of action that may interact with THC to determine the health effects of the drug. For example, CBD may act to reduce some acute effects of THC through negative allosteric modulation of the CBR1 receptor (Hayakawa et al., 2008; Laprairie et al., 2015). There is however, also some evidence that CBD may increase plasma concentrations of THC (Arkell et al., 2019; Nadulski et al., 2005). The extent to which $\mathrm{CBD}$ acts via contrasting mechanisms such as these within and across individuals could account for the mixed and sometimes opposing effects of CBD reported in the literature to date. Further research should focus on establishing standardised methods for investigating these effects. One option might be for future research to focus on administration routes and doses which have the most ecological validity (such as vaporised or smoked cannabis, or sublingual methods for medicinal use). It may be helpful to establish standardised units of measurement of THC and CBD in cannabis to allow for more meaningful comparisons to be made between studies (T. P. Freeman \& Lorenzetti, in press). Further evidence is needed to strengthen the evidence base on how CBD influences the effects of THC, and to establish dose-response. As policymakers aim to guide regulation strategies and 
educate consumers on how to minimise the risks of cannabis use, this is an important issue for future research.

\subsection{Strengths and limitations}

This review followed PRISMA guidelines for conducting and reporting systematic reviews (Higgins \& Green, 2008; Liberati et al., 2009). Two independent raters were used for both searches and data extraction. This study used the Cochrane risk of bias tool (Higgins et al., 2016) to evaluate methodological criteria. This is the first systematic review to assess outcomes for human studies evaluating the moderating effects of CBD on the acute effects of THC. This review aimed to provide a narrative synthesis of a large variety of outcomes using a wide range of measures. To give a comprehensive picture of findings, where possible this review has incorporated all outcomes reported where THC with and without CBD were compared. In order to directly assess the acute effects of THC with and without $\mathrm{CBD}$, it was necessary only to include studies that directly compared a matched dose and route of administration of THC with and without CBD. Therefore, repeated dosing studies and studies which looked at a range of administration methods were excluded. Cannabis contains over a hundred cannabinoids (such as cannabinol and tetrahydrocannabivarin). Similarly, there are more than a hundred terpenoids and some of these have the potential to moderate the effects and interactions of cannabinoids (Russo, 2011). Further research is needed to investigate how terpenoids and cannabinoids other than THC and CBD influence the effects of cannabis in humans.

Methodological issues with the identified studies included: limited information about how withdrawals were managed; inadequate description or randomisation; treatment 
allocation blinding and information about whether order effects were accounted for in statistical analyses. An additional limitation in some studies is that they included very small sample sizes. Although rigorous experimental designs which use repeated measures may afford higher statistical power, some studies may have nevertheless been underpowered when taking into account the effect sizes reported (Machin, Campbell, Tan, \& Tan, 2018). Not all studies accounted for multiple analyses in their statistical analysis plan. Correlations for treatment response across conditions for individual participants was not considered in the analysis plan of several studies, which may have reduced power in crossover studies (Sedgwick, 2015).

\subsection{Conclusions}

The cannabis plant contains more than a hundred different cannabinoids and many of these may interact to determine the drug's effects. At present, there is some evidence to suggest that CBD may reduce some of the effects of THC. However, significant variability was reported in the effects of these compounds both between studies and across individuals within studies. Further research is needed to investigate how CBD interacts with THC across a range of doses and routes of administration to gain further insight into how it might influence the benefits and harms of THC. 


\section{Appendices}

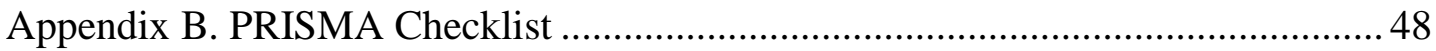

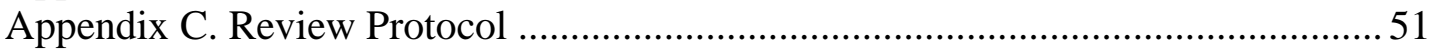

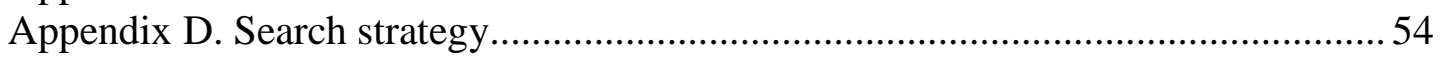

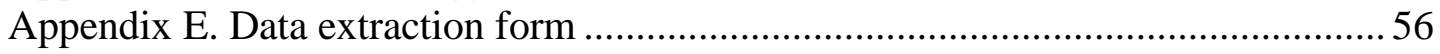

Appendix F. Studies excluded in full-text search .................................................5 57

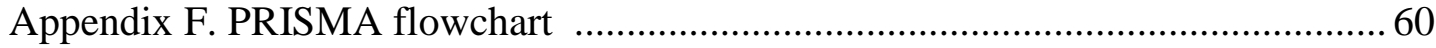

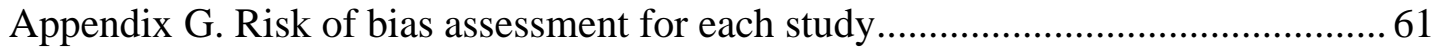

Appendix H. Psychological effects of drug action scale........................................... 63 
Appendix A. PRISMA Checklist

\begin{tabular}{|c|c|c|c|}
\hline Section/topic & $\#$ & Checklist item & $\begin{array}{l}\text { Reported } \\
\text { on page \# }\end{array}$ \\
\hline \multicolumn{4}{|l|}{ TITLE } \\
\hline Title & 1 & Identify the report as a systematic review, meta-analysis, or both. & 1 \\
\hline \multicolumn{4}{|l|}{ ABSTRACT } \\
\hline Structured summary & 2 & $\begin{array}{l}\text { Provide a structured summary including, as applicable: background; objectives; data sources; study } \\
\text { eligibility criteria, participants, and interventions; study appraisal and synthesis methods; results; } \\
\text { limitations; conclusions and implications of key findings; systematic review registration number. }\end{array}$ & 2 \\
\hline \multicolumn{4}{|l|}{ INTRODUCTION } \\
\hline Rationale & 3 & Describe the rationale for the review in the context of what is already known. & 8 \\
\hline Objectives & 4 & $\begin{array}{l}\text { Provide an explicit statement of questions being addressed with reference to participants, interventions, } \\
\text { comparisons, outcomes, and study design (PICOS). }\end{array}$ & 9 \\
\hline \multicolumn{4}{|l|}{ METHODS } \\
\hline Protocol and registration & 5 & $\begin{array}{l}\text { Indicate if a review protocol exists, if and where it can be accessed (e.g., Web address), and, if available, } \\
\text { provide registration information including registration number. }\end{array}$ & 9 \\
\hline Eligibility criteria & 6 & $\begin{array}{l}\text { Specify study characteristics (e.g., PICOS, length of follow-up) and report characteristics (e.g., years } \\
\text { considered, language, publication status) used as criteria for eligibility, giving rationale. }\end{array}$ & 9,10 \\
\hline Information sources & 7 & $\begin{array}{l}\text { Describe all information sources (e.g., databases with dates of coverage, contact with study authors to } \\
\text { identify additional studies) in the search and date last searched. }\end{array}$ & 11 \\
\hline Search & 8 & $\begin{array}{l}\text { Present full electronic search strategy for at least one database, including any limits used, such that it } \\
\text { could be repeated. }\end{array}$ & 11,54 \\
\hline Study selection & 9 & $\begin{array}{l}\text { State the process for selecting studies (i.e., screening, eligibility, included in systematic review, and, if } \\
\text { applicable, included in the meta-analysis). }\end{array}$ & 11 \\
\hline
\end{tabular}




\begin{tabular}{|c|c|c|c|}
\hline Data collection process & 10 & $\begin{array}{l}\text { Describe method of data extraction from reports (e.g., piloted forms, independently, in duplicate) and any } \\
\text { processes for obtaining and confirming data from investigators. }\end{array}$ & 11 \\
\hline Data items & 11 & $\begin{array}{l}\text { List and define all variables for which data were sought (e.g., PICOS, funding sources) and any } \\
\text { assumptions and simplifications made. }\end{array}$ & 11 \\
\hline $\begin{array}{l}\text { Risk of bias in individual } \\
\text { studies }\end{array}$ & 12 & $\begin{array}{l}\text { Describe methods used for assessing risk of bias of individual studies (including specification of whether } \\
\text { this was done at the study or outcome level), and how this information is to be used in any data synthesis. }\end{array}$ & 12 \\
\hline Summary measures & 13 & State the principal summary measures (e.g., risk ratio, difference in means). & 12 \\
\hline Synthesis of results & 14 & $\begin{array}{l}\text { Describe the methods of handling data and combining results of studies, if done, including measures of } \\
\left.\text { consistency (e.g., }\left.\right|^{2}\right) \text { for each meta-analysis. }\end{array}$ & 25 \\
\hline Section/topic & \# & Checklist item & $\begin{array}{l}\text { Reported } \\
\text { on page \# }\end{array}$ \\
\hline $\begin{array}{l}\text { Risk of bias across } \\
\text { studies }\end{array}$ & 15 & $\begin{array}{l}\text { Specify any assessment of risk of bias that may affect the cumulative evidence (e.g., publication bias, } \\
\text { selective reporting within studies). }\end{array}$ & 12 \\
\hline Additional analyses & 16 & $\begin{array}{l}\text { Describe methods of additional analyses (e.g., sensitivity or subgroup analyses, meta-regression), if done, } \\
\text { indicating which were pre-specified. }\end{array}$ & NA \\
\hline \multicolumn{4}{|l|}{ RESULTS } \\
\hline Study selection & 17 & $\begin{array}{l}\text { Give numbers of studies screened, assessed for eligibility, and included in the review, with reasons for } \\
\text { exclusions at each stage, ideally with a flow diagram. }\end{array}$ & 12 \\
\hline Study characteristics & 18 & $\begin{array}{l}\text { For each study, present characteristics for which data were extracted (e.g., study size, PICOS, follow-up } \\
\text { period) and provide the citations. }\end{array}$ & $13-22$ \\
\hline $\begin{array}{l}\text { Risk of bias within } \\
\text { studies }\end{array}$ & 19 & Present data on risk of bias of each study and, if available, any outcome level assessment (see item 12). & 24 \\
\hline $\begin{array}{l}\text { Results of individual } \\
\text { studies }\end{array}$ & 20 & $\begin{array}{l}\text { For all outcomes considered (benefits or harms), present, for each study: (a) simple summary data for } \\
\text { each intervention group (b) effect estimates and confidence intervals, ideally with a forest plot. }\end{array}$ & $15-22$ \\
\hline Synthesis of results & 21 & Present results of each meta-analysis done, including confidence intervals and measures of consistency. & $25-38$ \\
\hline $\begin{array}{l}\text { Risk of bias across } \\
\text { studies }\end{array}$ & 22 & Present results of any assessment of risk of bias across studies (see Item 15). & 24 \\
\hline
\end{tabular}




\begin{tabular}{|l|r|l|l|}
\hline Additional analysis & 23 & $\begin{array}{l}\text { Give results of additional analyses, if done (e.g., sensitivity or subgroup analyses, meta-regression [see } \\
\text { Item 16]). }\end{array}$ & NA \\
\hline \hline DISCUSSION & 24 & $\begin{array}{l}\text { Summarize the main findings including the strength of evidence for each main outcome; consider their } \\
\text { relevance to key groups (e.g., healthcare providers, users, and policy makers). }\end{array}$ & $39-44$ \\
\hline Summary of evidence & 25 & $\begin{array}{l}\text { Discuss limitations at study and outcome level (e.g., risk of bias), and at review-level (e.g., incomplete } \\
\text { retrieval of identified research, reporting bias). }\end{array}$ & 45 \\
\hline Limitations & 26 & $\begin{array}{l}\text { Provide a general interpretation of the results in the context of other evidence, and implications for future } \\
\text { research. }\end{array}$ & 46 \\
\hline Conclusions & 27 & $\begin{array}{l}\text { Describe sources of funding for the systematic review and other support (e.g., supply of data); role of } \\
\text { funders for the systematic review. }\end{array}$ & 1 \\
\hline \hline FUNDING &
\end{tabular}


Appendix B. Review Protocol

\author{
How does cannabidiol (CBD) influence the acute effects of delta-9- \\ tetrahydrocannabinol ( $\triangle 9$-THC) in humans? A systematic review \\ Abigail Freeman, Rachel Lees, Katherine Petrilli, Rob Saunders, Chandni Hindocha, Claire Mokrysz, \\ Citation \\ Tom Freeman, Valerie Curran \\ Abigail Freeman, Rachel Lees, Katherine Petrilli, Rob Saunders, Chandni Hindocha, Claire \\ Mokrysz, Tom Freeman, Valerie Curran. How does cannabidiol (CBD) influence the acute \\ effects of delta-9- tetrahydrocannabinol $(\triangle 9-T H C)$ in humans? A systematic review. \\ PROSPERO $2019 \quad$ CRD42019126994 Available \\ from: http://www.crd.york.ac.uk/PROSPERO/display record.php?ID=CRD42019126994
}

\title{
Review question
}

How does CBD influence the acute effects of $\Delta 9$-THC?

\section{Searches}

We will search the following electronic bibliographic databases: MEDLINE, EMBASE, PsycINFO, and CINAHL Plus. The search strategy will include only terms relating to or describing the intervention ( $\triangle 9-\mathrm{THC}$ and $\mathrm{CBD}$ ). The terms will be combined with the Ovid filter for human studies and studies published in English. The search terms will be adapted for use with other bibliographic databases in combination with database-specific filters for human trials and peer-reviewed articles, where these are available.

There will be no date restrictions. The searches will be re-run just before the final synthesis and further studies retrieved for inclusion. Papers must be published in English.

\section{Types of study to be included}

Inclusion criteria: We will include human studies with an experimental design which include random allocation to (i) a fixed dose of THC (THC), and (ii) the same fixed dose of THC administered with CBD (THC+CBD). Participants must be compared to a matched control group, or act as their own controls (crossover design). The included papers must be peerreviewed.

\section{Exclusion criteria:}

Conference extracts or abstracts, theses, reviews, supplements, editorial reports, correspondence, non-peer reviewed material e.g., books extracts, notes, and letters.

Animal studies.

\section{Condition or domain being studied}

The acute administration of $\triangle 9-\mathrm{THC}$ and $\mathrm{CBD}$ in humans.

\section{Participants/population}

Inclusion: Human participants

Exclusion: None

\section{Intervention(s), exposure(s)}

Studies must include both a) a condition or group in which delta-9-tetrahydrocannabinol $(\Delta 9$ $\mathrm{THC} / \mathrm{THC} /$ tetrahydrocannabinol/dronabinol) is acutely administered under experimental conditions, and b) a matched condition or group where the same dose of $\triangle 9-\mathrm{THC}$ is acutely administered together with cannabidiol (CBD).

Comparator(s)/control

Placebo or a control condition where there is no drug administered, for example, a pre-drug measurement or baseline measurement. This is necessary to evaluate the acute effects of THC.

\section{Context}

Human laboratory studies which include healthy or clinical populations. 


\title{
Main outcome(s)
}

Establishing how CBD influences the acute effects of THC in humans (change in THC-induced effect when THC is administered with CBD).

\section{Additional outcome(s)}

None.

\section{Data extraction (selection and coding)}

Titles and/or abstracts of studies retrieved using the search strategy and those from additional sources will be screened independently by two reviewers to identify studies that potentially meet the inclusion criteria outlined above. The full text of these potentially eligible studies will be retrieved and independently assessed for eligibility by two review team members. Any disagreement between them over the eligibility of particular studies will be resolved through discussion with a third reviewer.

A standardised, pre-piloted form will be used to extract data from the included studies for assessment of study quality and evidence synthesis. Extracted information will include: study setting; study population and details of the dose and route of administration for THC and CBD, THC:CBD ratio; study methodology; recruitment and study completion rates; outcomes and times of measurement; information for assessment of the risk of bias. Two reviewers will extract data, discrepancies will be identified and resolved through discussion with a third reviewer where necessary. A subset of the extracted data will be randomly checked by a third reviewer.

\section{Risk of bias (quality) assessment}

Two reviewers will independently assess the risk of bias in included studies by considering the criteria set out by the Cochrane's risk of bias (RoB2) assessment tool as appropriate for the study design. Disagreements between the reviewers over the risk of bias in particular studies will be resolved by discussion, with involvement of a third review author where necessary.

\section{Strategy for data synthesis}

We will provide a narrative synthesis of the findings from the included studies, structured around the type of intervention, type of outcome and intervention content. We will provide summaries of intervention effects for each study. From initial scoping of the existing literature, we anticipate that the opportunity for meta-analysis may be limited because of the range of different outcomes measured across studies.

\section{Analysis of subgroups or subsets}

It is not expected that the studies will be reviewed separately for different groups. However, outcomes for different drug doses may be presented separately.

\section{Contact details for further information}

Abigail Freeman

abigail.freeman@ucl.ac.uk

\section{Organisational affiliation of the review \\ University College London}

\author{
Review team members and their organisational affiliations \\ Ms Abigail Freeman. University College London \\ Miss Rachel Lees. University College London, London, UK \\ Miss Katherine Petrilli. University College London, London, UK \\ Dr Rob Saunders. University College London, London, UK \\ Dr Chandni Hindocha. University College London, London, UK \\ Dr Claire Mokrysz. University College London, London, UK \\ Dr Tom Freeman. University of Bath, Bath, UK \\ Professor Valerie Curran. University College London, London, UK
}

\section{Type and method of review}


Narrative synthesis, Systematic review

Anticipated or actual start date

24 February 2019

Anticipated completion date

01 October 2019

Funding sources/sponsors

None

Conflicts of interest

None

Language

English

Country

England

Stage of review

Review Ongoing

Subject index terms status

Subject indexing assigned by CRD

Subject index terms

Cannabidiol; Dronabinol; Humans

Date of registration in PROSPERO

18 March 2019

Date of publication of this version

18 March 2019

Details of any existing review of the same topic by the same authors

None

Stage of review at time of this submission

Stage

Started Completed

Preliminary searches

Yes No

Piloting of the study selection process

No No

Formal screening of search results against eligibility criteria

No No

Data extraction

No No

Risk of bias (quality) assessment

No No

Data analysis

No No

\section{Versions}

18 March 2019

PROSPERO

This information has been provided by the named contact for this review. CRD has accepted this information in good faith and registered the review in PROSPERO. The registrant confirms that the information supplied for this submission is accurate and complete. CRD bears no responsibility or liability for the content of this registration record, any associated files or external websites. 
Appendix C. Search strategy

Search Strategy: Embase 1974 to 2019 February 27

\begin{tabular}{|c|c|c|}
\hline \# & Searches & Results \\
\hline 1 & cannabis*.tw. & 19528 \\
\hline 2 & $\mathrm{THC}^{*} . \mathrm{tw}$. & 12293 \\
\hline 3 & tetrahydrocannabinol*.tw. & 7913 \\
\hline 4 & delta-9-tetrahydrocannabinol*.tw. & 1913 \\
\hline 5 & dronabinol*.tw. & 490 \\
\hline 6 & Dronabinol/ & 7043 \\
\hline 7 & Dronabinol/ & 30687 \\
\hline 8 & $\mathrm{cbd}^{*} . \mathrm{tw}$ & 12647 \\
\hline 9 & Cannabidiol*.tw. & 2835 \\
\hline 10 & Cannabidiol/ & 3660 \\
\hline 11 & marijuana*.tw. & 14832 \\
\hline 12 & 8 or 9 or 10 & 14970 \\
\hline 13 & $\begin{array}{l}\text { (books or review or erratum or note or editorial or letter or "short survey" or tombstone } \\
\text { or "conference paper" or "conference abstract").pt. }\end{array}$ & 9350415 \\
\hline 14 & tetrahydrocannabinol/ or dronabinol/ or cannabis/ & 38377 \\
\hline 15 & 1 or 2 or 3 or 4 or 5 or 6 or 7 or 11 or 14 & 55349 \\
\hline 16 & 12 and 15 & 3241 \\
\hline 17 & 16 not 13 & 1820 \\
\hline 18 & limit 17 to (human and English language) & 721 \\
\hline
\end{tabular}

Search Strategy: Ovid MEDLINE(R) and Epub Ahead of Print, In-Process \& Other Non-Indexed Citations and Daily 1946 to February 27, 2019

\begin{tabular}{|c|c|c|}
\hline \# & Searches & Results \\
\hline 1 & cannabis*.tw. & 14086 \\
\hline 2 & THC*.tw. & 8799 \\
\hline 3 & tetrahydrocannabinol*.tw. & 6408 \\
\hline 4 & delta-9-tetrahydrocannabinol ${ }^{*}$.tw. & 3234 \\
\hline 5 & dronabinol*.tw. & 308 \\
\hline 6 & Dronabinol/ & 6606 \\
\hline 7 & Cannabis/ & 8197 \\
\hline 8 & 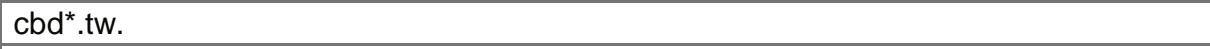 & 7736 \\
\hline 9 & Cannabidiol*.tw. & 2052 \\
\hline 10 & Cannabidiol/ & 1255 \\
\hline 11 & marijuana*.tw. & 11743 \\
\hline 12 & 8 or 9 or 10 & 8769 \\
\hline 13 & $\begin{array}{l}\text { (books or review or erratum or note or editorial or letter or "short survey" or tombstone } \\
\text { or "conference paper" or "conference abstract").pt. }\end{array}$ & 3959425 \\
\hline 14 & tetrahydrocannabinol/ or dronabinol/ or cannabis/ & 13133 \\
\hline 15 & 1 or 2 or 3 or 4 or 5 or 6 or 7 or 11 or 14 & 35691 \\
\hline 16 & 12 and 15 & 1765 \\
\hline 17 & 16 not 13 & 1399 \\
\hline 18 & limit 17 to (human and English language) & 535 \\
\hline
\end{tabular}


Search Strategy: PsycINFO 1806 to February Week 12019

\begin{tabular}{|c|c|c|}
\hline$\#$ & Searches & Results \\
\hline 1 & cannabis*.tw. & 9350 \\
\hline 2 & THC*.tw. & 2179 \\
\hline 3 & tetrahydrocannabinol*.tw. & 2240 \\
\hline 4 & delta-9-tetrahydrocannabinol*.tw. & 892 \\
\hline 5 & dronabinol*.tw. & 95 \\
\hline 6 & $\mathrm{cbd}^{*} . \mathrm{tw}$. & 846 \\
\hline 7 & Cannabidiol*.tw. & 555 \\
\hline 8 & marijuana*.tw. & 9477 \\
\hline 9 & $\begin{array}{l}\text { (books or review or erratum or note or editorial or letter or "short survey" or tombstone } \\
\text { or "conference paper" or "conference abstract").pt. }\end{array}$ & 0 \\
\hline 10 & exp CANNABIS/ & 7501 \\
\hline 11 & exp MARIJUANA/ & 2902 \\
\hline 12 & exp Marijuana/ or exp Tetrahydrocannabinol/ or exp Cannabis/ & 8462 \\
\hline 13 & 1 or 2 or 3 or 4 or 5 or 8 or 10 or 11 or 12 & 19213 \\
\hline 14 & 6 or 7 & 1031 \\
\hline 15 & 13 and 14 & 459 \\
\hline 16 & 15 not 9 & 459 \\
\hline 17 & limit 16 to (human and English language) & 250 \\
\hline
\end{tabular}

\section{CINHAL Plus up to February Week 12019}

(MH "cannabis" or "cannabis" or "THC" or "tetrahydrocannabinol" or "delta-9tetrahydrocannabinol or "dronabinol" ) AND ( cbd or "cannabidiol" ) 


\section{Appendix D. Data extraction form}

\begin{tabular}{|c|c|}
\hline Reviewer: & Notes \\
\hline Study ID & \\
\hline $\begin{array}{l}\text { Experimental design? Type of study: (e.g. placebo-controlled, double-blind, parallel, } \\
\text { crossover, non-RCT) }\end{array}$ & \\
\hline $\begin{array}{l}\text { Random allocation? How as it randomised, Unit of randomisation (by individuals, } \\
\text { groups) }\end{array}$ & \\
\hline $\begin{array}{l}\text { Placebo or a control condition where measurement is taken with no drug } \\
\text { administered? }\end{array}$ & \\
\hline $\begin{array}{l}\text { Types of intervention: (i) a fixed dose of THC, and (ii) the same fixed dose of THC } \\
\text { administered with CBD (THC+CBD)? Any other interventions? }\end{array}$ & \\
\hline Assessment of acute effects: i.e. single dose or multiple doses in a single session & \\
\hline Include or Exclude & \\
\hline $\begin{array}{l}\text { Reason: repeated dosing study, no baseline measurement, No THC+CBD or meets } \\
\text { inclusion criteria - list }\end{array}$ & \\
\hline Do not proceed if excluded. & \\
\hline Aim of study as stated & \\
\hline $\begin{array}{l}\text { Population description: For example, healthy current users, healthy ever users, } \\
\text { clinical population, CUD }\end{array}$ & \\
\hline Abstinence: How many hours drug-free before dosing? & \\
\hline Inclusion criteria/Exclusion criteria & \\
\hline Number of participants & \\
\hline $\begin{array}{l}\text { If parallel Include information for each group (i.e. intervention and controls) under } \\
\text { study }\end{array}$ & \\
\hline Withdrawals and exclusions & \\
\hline Were there any significant baseline imbalances? & \\
\hline Were patients who entered the study adequately accounted for? & \\
\hline Age; range, median mean, $\mathrm{SD}$ & \\
\hline $\operatorname{Sex}(\mathrm{M}, \mathrm{F})$ & \\
\hline Race/Ethnicity & \\
\hline Cannabis use status: current and historical & \\
\hline Co-morbidities \& other relevant demographics & \\
\hline $\begin{array}{l}\text { Intervention \& control (route of admin, content, dose, schedule) For example, } \\
\text { smoked THC 8mg; oral CBD 800mg }\end{array}$ & \\
\hline Dosing schedule: For example, CBD administered one hour before THC dose & \\
\hline $\begin{array}{l}\text { Sample size calculation: What assumptions were made? Were these assumptions } \\
\text { appropriate? }\end{array}$ & \\
\hline A potential conflict of interest from funding? Y / N / unclear & \\
\hline Types of outcome measures: e.g. fMRI, psychological, pharmacokinetic & \\
\hline Outcomes comparing THC vs THC+CBD: $1 / 2$ short sentences for each outcome & \\
\hline Key conclusions of the study & \\
\hline Notes & \\
\hline Limitations/strengths & \\
\hline
\end{tabular}


Appendix E. Studies excluded in full-text search

Table E. 1. Study characteristics for inclusion criteria for each study excluded in a full-text search

\begin{tabular}{|c|c|c|c|c|c|c|}
\hline Study & Design & Randomisation & $\begin{array}{c}\text { Placebo or } \\
\text { baseline }\end{array}$ & Intervention & Treatment schedule & $\begin{array}{l}\text { Reason for } \\
\text { exclusion }\end{array}$ \\
\hline $\begin{array}{l}\text { Agurell et al. } \\
\text { (1981) }\end{array}$ & $\begin{array}{l}\text { Crossover } \\
\text { study }\end{array}$ & $\begin{array}{l}\text { Balanced crossover } \\
\text { sequence }\end{array}$ & $\begin{array}{l}\text { No placebo or } \\
\text { baseline } \\
\text { measurement }\end{array}$ & $\begin{array}{l}\text { Oral } 20 \mathrm{mg} \text { of THC and placebo; } \\
\text { oral } 20 \mathrm{mg} \text { of THC, and oral } 40 \\
\mathrm{mg} \text { of CBD; oral } 20 \mathrm{mg} \text { of THC } \\
\text { and oral } 40 \mathrm{mg} \text { of CBN. }\end{array}$ & $\begin{array}{l}\text { Single dose, weekly } \\
\text { interval }\end{array}$ & $\begin{array}{l}\text { No baseline } \\
\text { measurement pre- } \\
\text { THC }\end{array}$ \\
\hline $\begin{array}{l}\text { Babalonis et } \\
\text { al. (2017) }\end{array}$ & $\begin{array}{l}\text { Double-blind, } \\
\text { crossover } \\
\text { study }\end{array}$ & Random allocation & Placebo & $\begin{array}{l}\text { Oral cannabidiol }(0,200,400,800 \\
\mathrm{mg}) \text { alone and in combination } \\
\text { with smoked marijuana } 0.01 \% \text {; } \\
5.3-5.8 \% \text { THC }\end{array}$ & $\begin{array}{l}8 \text { once-weekly } \\
\text { outpatient sessions } \\
(7.5 \mathrm{~h})\end{array}$ & $\begin{array}{l}\text { No active } \\
\text { THC+CBD } \\
\text { condition }\end{array}$ \\
\hline $\begin{array}{l}\text { Berman, } \\
\text { Symonds, and } \\
\text { Birch (2004) }\end{array}$ & $\begin{array}{l}\text { Double-blind, } \\
\text { crossover } \\
\text { study }\end{array}$ & $\begin{array}{l}\text { Randomly allocated } \\
\text { to treatment order } \\
\text { by a computer }\end{array}$ & Placebo & $\begin{array}{l}\text { Oromucosal spray GW-1000-02: } \\
\text { Sativex THC:CBD) 1:1 ratio; } \\
\text { GW-2000-02 THC; placebo }\end{array}$ & $\begin{array}{l}\text { Baseline period of } 2 \\
\text { weeks, followed by } \\
\text { three, 2-week } \\
\text { treatment periods }\end{array}$ & $\begin{array}{l}\text { Repeated dosing } \\
\text { study }\end{array}$ \\
\hline $\begin{array}{l}\text { Brady et al. } \\
(2004)\end{array}$ & $\begin{array}{l}\text { Crossover } \\
\text { study }\end{array}$ & NA & Open label & $\begin{array}{l}\text { Sublingual spray THC }(2.5 \mathrm{mg}) \\
\text { THC }(2.5 \mathrm{mg})+\operatorname{CBD}(2.5 \mathrm{mg})\end{array}$ & $\begin{array}{l}\text { Repeated dosing } 16 \\
\text { weeks }\end{array}$ & $\begin{array}{l}\text { Repeated dosing } \\
\text { study }\end{array}$ \\
\hline $\begin{array}{l}\text { Efron and } \\
\text { Freeman } \\
(2018)\end{array}$ & NA & NA & NA & NA & NA & Commentary \\
\hline $\begin{array}{l}\text { Guy and Flint } \\
(2003)\end{array}$ & $\begin{array}{l}\text { Partially } \\
\text { double-blind, } \\
\text { crossover } \\
\text { study }\end{array}$ & $\begin{array}{l}\text { Partially } \\
\text { randomised, }\end{array}$ & Placebo & $\begin{array}{l}\text { Sublingual drops placebo; THC } \\
(20 \mathrm{mg}) ; \text { THC }(20 \mathrm{mg})+\text { CBD } \\
(20 \mathrm{mg})\end{array}$ & Single dose & $\begin{array}{l}\mathrm{THC}+\mathrm{CBD} \\
\text { condition is open } \\
\text { label }\end{array}$ \\
\hline $\begin{array}{l}\text { Guy and } \\
\text { Robson (2004) }\end{array}$ & $\begin{array}{l}\text { Four-way } \\
\text { crossover } \\
\text { study }\end{array}$ & $\begin{array}{l}\text { Randomised; } \\
\text { Williams } \\
\text { Square Design }\end{array}$ & Open label & $\begin{array}{l}\text { Sublingual, buccally, oro- } \\
\text { pharyngenally, or oral THC } 10 \mathrm{mg} \\
+ \text { CBD 10mg }\end{array}$ & $\begin{array}{l}\text { Single dose; } 6 \text { day } \\
\text { washout }\end{array}$ & $\begin{array}{l}\text { No THC only } \\
\text { comparator }\end{array}$ \\
\hline $\begin{array}{l}\text { Ilan, Gevins, } \\
\text { Coleman, } \\
\text { ElSohly, and } \\
\text { de Wit (2005) }\end{array}$ & $\begin{array}{l}\text { Double-blind, } \\
\text { crossover } \\
\text { study }\end{array}$ & Randomised & Placebo & $\begin{array}{l}\text { Smoked Placebo; smoked THC } \\
1.91 \% \text {, Low CBC } 0.6 \% \text { and Low } \\
\text { CBD } 0.2 \% \text {; smoked THC } 2.86 \% \text {, } \\
\text { Low CBC } 0.1 \% \text { and High CBD }\end{array}$ & $\begin{array}{l}\text { Single dose, weekly } \\
\text { interval }\end{array}$ & $\begin{array}{l}\text { Not comparable } \\
\text { matched doses for } \\
\text { THC in both THC }\end{array}$ \\
\hline
\end{tabular}


$1.0 \%$; smoked THC1.88\%, Low

and $\mathrm{THC}+\mathrm{CBD}$

CBC $0.1 \%$ and High CBD 1.52\%;

condition

smoked THC 3.09\%, High CBC

$0.5 \%$ and Low CBD $0.08 \%$

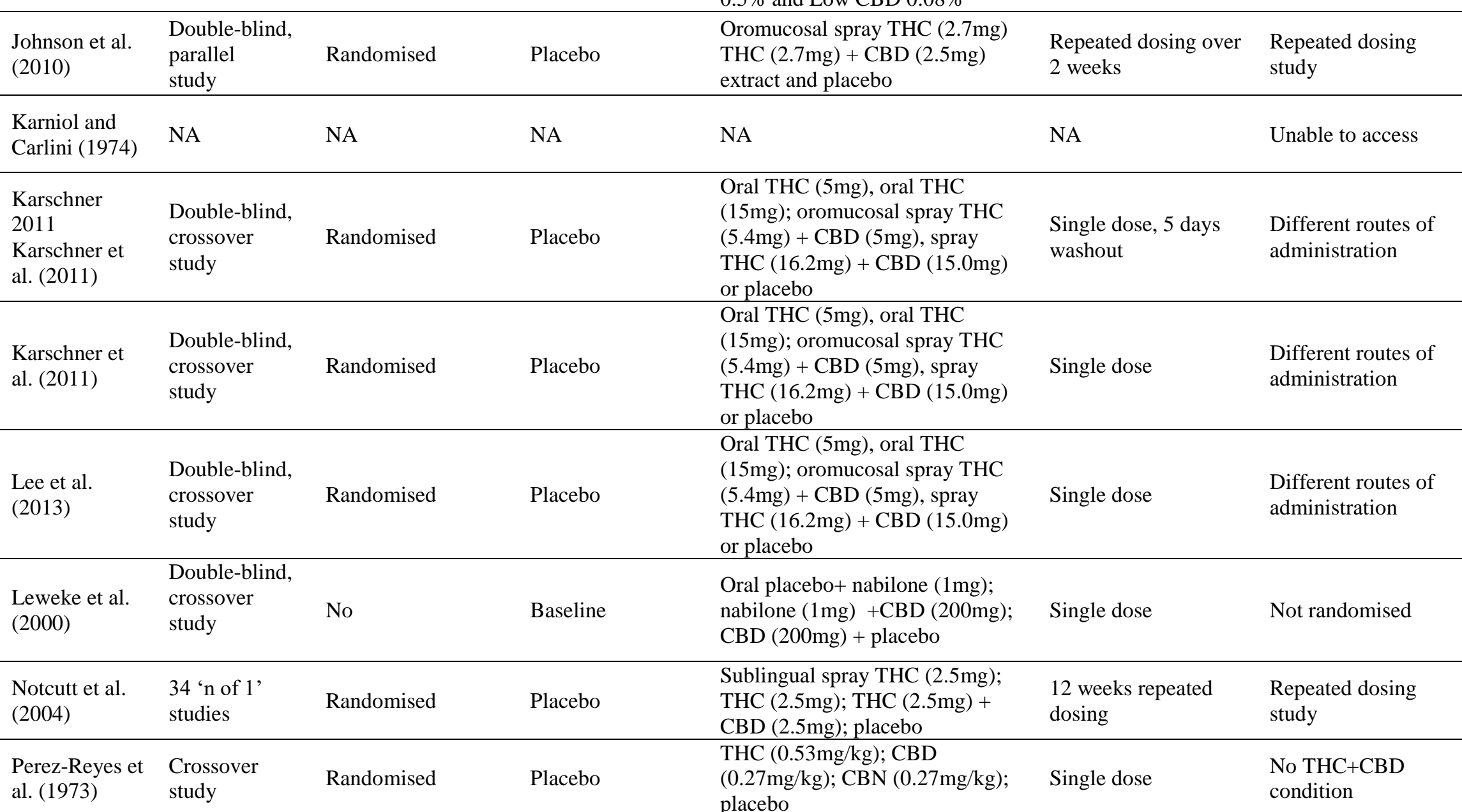




\begin{tabular}{|c|c|c|c|c|c|c|}
\hline $\begin{array}{l}\text { Perry, Ton, } \\
\text { and Allan } \\
(2018)\end{array}$ & NA & NA & NA & NA & NA & Review \\
\hline $\begin{array}{l}\text { Solowij et al. } \\
(2019)\end{array}$ & $\begin{array}{l}\text { Crossover } \\
\text { study }\end{array}$ & Randomised & Placebo & $\begin{array}{l}\text { THC } 8 \text { + CBD } 4 \text { mg; THC } 8 \text { mg, } \\
\text { THC } 12 \text { + CBD 400; CBD } \\
\text { 400mg, Placebo }\end{array}$ & Single dose & $\begin{array}{l}\text { No comparison } \\
\text { between THC } 8+ \\
\text { CBD } 4 \mathrm{mg} \text {; THC } 8 \\
\text { mg alone; only } \\
\text { linear function } \\
\text { across all THC } \\
\text { conditions }\end{array}$ \\
\hline $\begin{array}{l}\text { Strasser et al. } \\
(2006)\end{array}$ & $\begin{array}{l}\text { Double-blind, } \\
\text { placebo- } \\
\text { controlled } \\
\text { study }\end{array}$ & $\begin{array}{l}\text { Randomly assigned } \\
(2: 2: 1)\end{array}$ & Placebo & $\begin{array}{l}\text { Oral cannabis extract } \\
\text { (standardized for } 2.5 \mathrm{mg} \text { THC and } \\
1 \mathrm{mg} \text { cannabidiol); THC ( } 2.5 \\
\mathrm{mg} \text { ); placebo }\end{array}$ & $\begin{array}{l}\text { Twice daily for } 6 \\
\text { weeks }\end{array}$ & $\begin{array}{l}\text { Repeated dosing } \\
\text { study }\end{array}$ \\
\hline $\begin{array}{l}\text { Schoedel et al. } \\
\text { (2011) }\end{array}$ & $\begin{array}{l}\text { Double-blind, } \\
\text { crossover } \\
\text { study }\end{array}$ & Randomised & $\begin{array}{l}\text { Placebo, and } \\
\text { baseline }\end{array}$ & $\begin{array}{l}\text { Oromucosal spray THC (10.8 mg) } \\
\text { + CBD (10 mg); THC (21.6 mg) } \\
\text { + CBD (20mg); THC (43.2 mg) } \\
\text { + CBD (40 mg); oral dronabinol } \\
\text { ( } 20 \mathrm{mg}) ; \text { dronabinol (40 mg), } \\
\text { placebo }\end{array}$ & $\begin{array}{l}\text { Single dose, } 2 \text { day } \\
\text { washout }\end{array}$ & $\begin{array}{l}\text { Not matched } \\
\text { control/dose }\end{array}$ \\
\hline $\begin{array}{l}\text { Valle et al. } \\
\text { (2015) }\end{array}$ & $\begin{array}{l}\text { Double-blind, } \\
\text { crossover } \\
\text { study }\end{array}$ & Randomised & Placebo & $\begin{array}{l}\text { Sublingual THC (7.5mg); CBD } \\
(7,5 \mathrm{mg}), \text { THC (7.5mg) + CBD } \\
(7.5 \mathrm{mg})\end{array}$ & Single dose & Abstract only \\
\hline $\begin{array}{l}\text { Wade et al. } \\
\text { (2003) }\end{array}$ & $\begin{array}{l}\text { Single-patient, } \\
\text { crossover } \\
\text { study }\end{array}$ & Randomised & Placebo & $\begin{array}{l}\text { Sublingual spray THC }(2.5 \mathrm{mg}) \text {; } \\
\text { CBD }(2.5 \mathrm{mg}) ; \text { THC }(2.5 \mathrm{mg})+ \\
\text { CBD }(2.5 \mathrm{mg}) ; \text { placebo }\end{array}$ & $\begin{array}{l}\text { Two week repeated } \\
\text { dosing }\end{array}$ & $\begin{array}{l}\text { Repeated dosing } \\
\text { study }\end{array}$ \\
\hline $\begin{array}{l}\text { Wade, } \\
\text { Makela, } \\
\text { Robson, } \\
\text { House, and } \\
\text { Bateman } \\
(2004)\end{array}$ & $\begin{array}{l}\text { Double-blind, } \\
\text { parallel study }\end{array}$ & Randomised & Placebo & $\begin{array}{l}\text { Sublingual spray THC }(2.5 \mathrm{mg}) \text {; } \\
\mathrm{CBD}(2.5 \mathrm{mg}) ; \text { THC }(2.5 \mathrm{mg})+ \\
\mathrm{CBD}(2.5 \mathrm{mg}) ; \text { placebo }\end{array}$ & $\begin{array}{l}\text { Six week repeated } \\
\text { dosing }\end{array}$ & $\begin{array}{l}\text { Repeated dosing } \\
\text { study } 1\end{array}$ \\
\hline $\begin{array}{l}\text { Yuan et al. } \\
(2017)\end{array}$ & Case report & NA & NA & 3-4 joints a day THC (18.6\%) & Repeated dosing & Case report \\
\hline
\end{tabular}




\section{Appendix F. PRISMA flowchart}

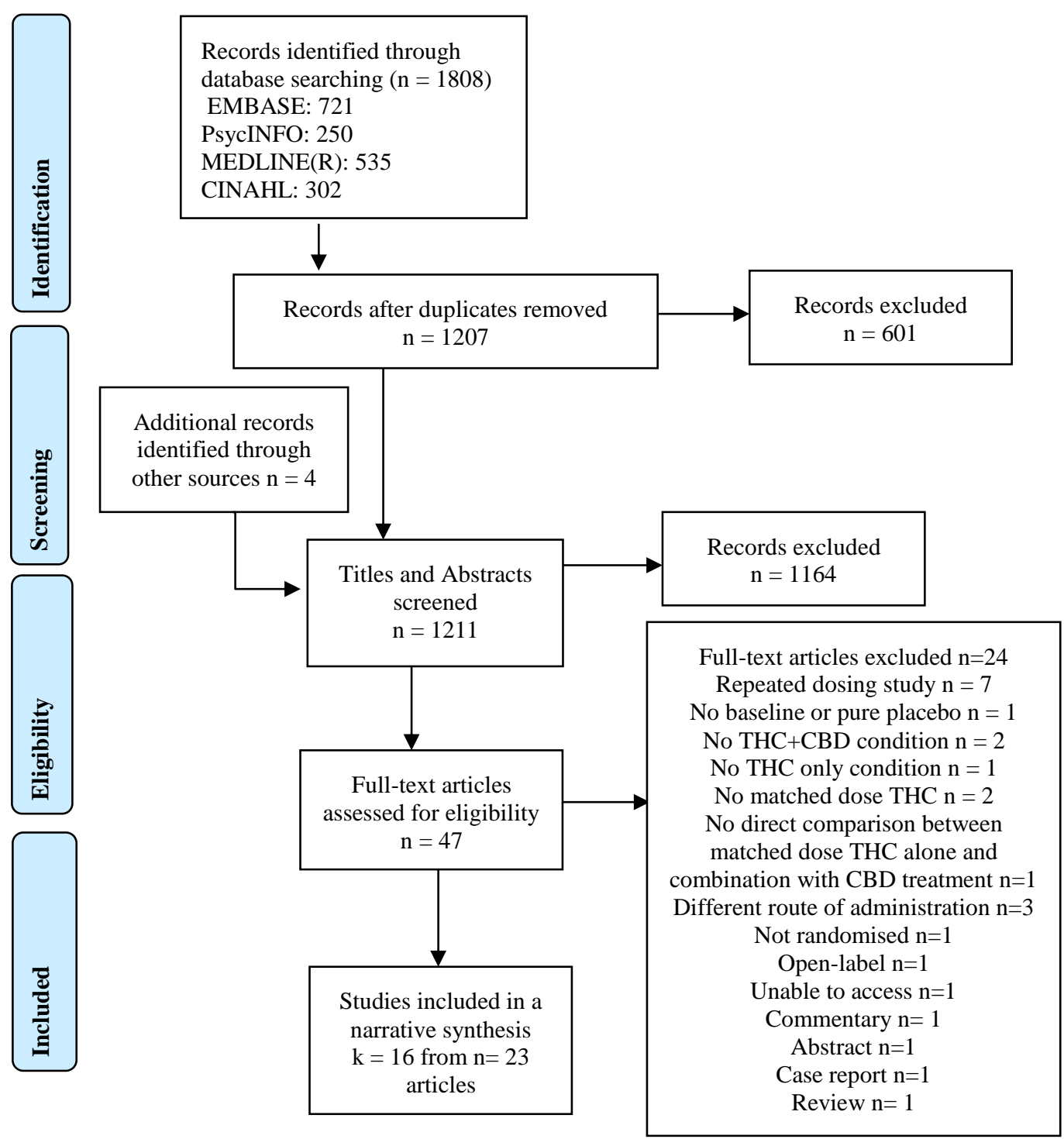

Figure 1. PRISMA flow diagram (Moher, Liberati, Tetzlaff, Altman, \& Group, 2009) 
Appendix G. Risk of bias assessment for each study

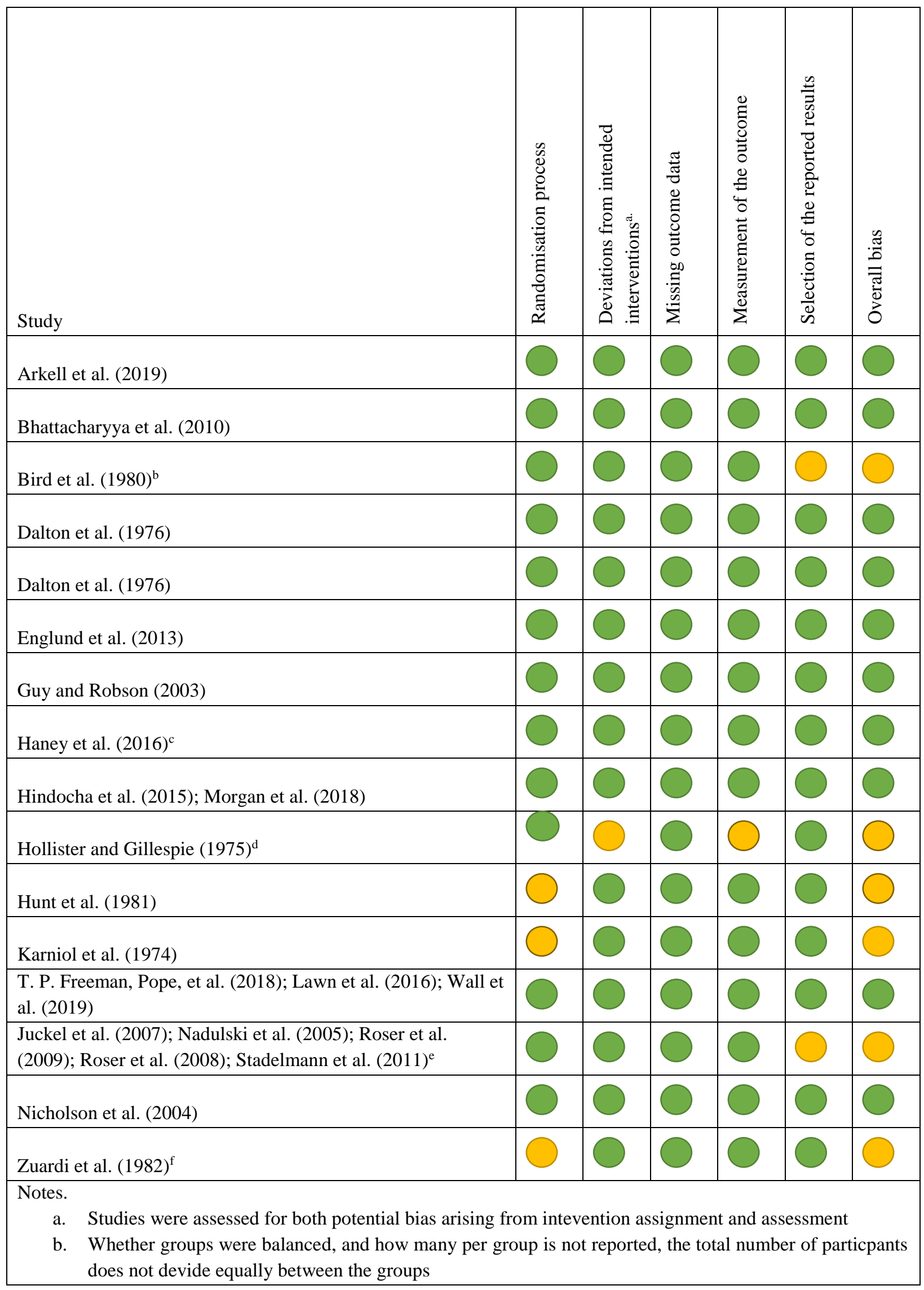


c. 31/50 participants completed raising some concerns about potential bias.

d. No indication of blinding, study states randomisation process so at least participant concealment is assumed by some concern noted. Study does not report statistics.

e. Study had fewer than $90-95 \%$ of particpants who were randomised complete the intervention

f. Some concerns about the randomisation and blinding of the study as this is not indicated in the article it seems reasonable to assume that as it was placebo cotrolled it would also be blinded. Treatments allocated in a different order but so each followed eachother, so its possible the experimeter would have been able to guess the drug allocation.

No issues

Some concerns 
Appendix H. Psychological effects of drug action scale

\section{The psychological effects of drug action were graded from 0 to 4 , according to the subjective report of at least three symptoms in a grade:}

Grade 0: nothing or slight anxiety.

Grade 1: slight feeling of well-being; feeling of lightness; paraesthesia in extremities; slight difficulty in concentration; dizziness; somnolence; cold hands and sweating.

Grade 2: definite feeling of well-being; euphoria; colours are brighter; intense paraesthesia; uninterested by the surroundings; some difficulty in reporting feelings; sometimes slight sensation of fear; intense difficulty in concentration.

Grade 3: marked sensation of euphoria intercalated with moments of apprehension; intense introspection with resistance to describing feelings; sensation of being watched; sounds are clearer and colours are brighter; laughing without reason; concentration almost impossible due to the rapid flow of ideas; extremities very heavy; unable to visualize intact objects with eyes closed (e.g. watch seen without numbers or hands).

Grade 4: feelings of well-being followed later by panic; intense sensation of being watched; coherent thoughts impossible due to the rapid flow of ideas; in general, subject knows what is happening, but loses the knowledge from time to time and panic starts; cenesthesia; striking visual hallucinations.

Taken from: Carlini, Karniol, Renault, and Schuster (1974) 


\section{References}

Agurell, S., Carlsson, S., Lindgren, J. E., Ohlsson, A., Gillespie, H., \& Hollister, L. (1981). Interactions of $\Delta 1$-tetrahydrocannabinol with cannabinol and cannabidiol following oral administration in man. Assay of cannabinol and cannabidiol by mass fragmentography. Experientia, 37(10), 1090-1092. doi:10.1007\%2FBF02085029

Arkell, T. R., Lintzeris, N., Kevin, R. C., Ramaekers, J. G., Vandrey, R., Irwin, C., . . . McGregor, I. S. (2019). Cannabidiol (CBD) content in vaporized cannabis does not prevent tetrahydrocannabinol (THC)-induced impairment of driving and cognition. Psychopharmacology. doi:10.1007/s00213-019-05246-8

Arndt, D. L., \& De Wit, H. (2017). Cannabidiol Does Not Dampen Responses to Emotional Stimuli in Healthy Adults. Cannabis and Cannabinoid Research, 2(1), 105-113. doi:10.1089/can.2017.0014

Babalonis, S., Haney, M., Malcolm, R. J., Lofwall, M. R., Votaw, V. R., Sparenborg, S., \& Walsh, S. L. (2017). Oral cannabidiol does not produce a signal for abuse liability in frequent marijuana smokers. Drug \& Alcohol Dependence, 172, 913. doi:10.1016/j.drugalcdep.2016.11.030

Ballard, M. E., Gallo, D. A., \& de Wit, H. (2012). Psychoactive drugs and false memory: comparison of dextroamphetamine and delta-9-tetrahydrocannabinol on false recognition. Psychopharmacology, 219(1), 15-24.

Ballard, M. E., Gallo, D. A., \& de Wit, H. (2013). Pre-encoding administration of amphetamine or THC preferentially modulates emotional memory in humans. Psychopharmacology, 226(3), 515-529.

Ben-Shabat, S., Fride, E., Sheskin, T., Tamiri, T., Rhee, M.-H., Vogel, Z., . . . Mechoulam, R. (1998). An entourage effect: inactive endogenous fatty acid glycerol esters enhance 2-arachidonoyl-glycerol cannabinoid activity. 
European journal of pharmacology, 353(1), 23-31. doi:10.1016/S00142999(98)00392-6

Berman, J. S., Symonds, C., \& Birch, R. (2004). Efficacy of two cannabis based medicinal extracts for relief of central neuropathic pain from brachial plexus avulsion: results of a randomised controlled trial. Pain, 112(3), 299-306. doi:10.1016/j.pain.2004.09.013

Bhattacharyya, S., Morrison, P. D., Fusar-Poli, P., Martin-Santos, R., Borgwardt, S., Winton-Brown, T., . . . McGuire, P. K. (2010). Opposite effects of delta-9tetrahydrocannabinol and cannabidiol on human brain function and psychopathology. Neuropsychopharmacology, 35(3), 764-774. doi:10.1038/npp.2009.184

Bird, K., Boleyn, T., Chesher, G., Jackson, D., Starmer, G., \& Teo, R. (1980). Intercannabinoid and cannabinoid-ethanol interactions and their effects on human performance. Psychopharmacology, $\quad 71(2), \quad$ 181-188. doi:10.1007/BF00434409

Bisogno, T., Hanuš, L., De Petrocellis, L., Tchilibon, S., Ponde, D. E., Brandi, I., . . . Di Marzo, V. (2001). Molecular targets for cannabidiol and its synthetic analogues: effect on vanilloid VR1 receptors and on the cellular uptake and enzymatic hydrolysis of anandamide. British Journal of Pharmacology, 134(4), 845-852. doi:10.1038/sj.bjp.0704327

Bloomfield, M. A. P., Hindocha, C., Green, S. F., Wall, M. B., Lees, R., Petrilli, K., . . . Freeman, T. P. (2018). The neuropsychopharmacology of cannabis: A review of human imaging studies. Pharmacology and Therapeutics, 195, 132161. doi:10.1016/j.pharmthera.2018.10.006 
Bonn-Miller, M. O., ElSohly, M. A., Loflin, M. J., Chandra, S., \& Vandrey, R. (2018). Cannabis and cannabinoid drug development: evaluating botanical versus single molecule approaches. International Review of Psychiatry, 30(3), 277284. doi:10.1080/09540261.2018

Bossong, M. G., Jansma, J. M., Bhattacharyya, S., \& Ramsey, N. F. (2014). Role of the endocannabinoid system in brain functions relevant for schizophrenia: An overview of human challenge studies with cannabis or $\Delta$ 9tetrahydrocannabinol (THC). Progress in Neuro-Psychopharmacology Biological Psychiatry, 52, 53-69.

Boutron, I., Page, M., Higgins, J., Altman, D., Lundh, A., \& Hróbjartsson, A. (2019). Chapter 7: Considering bias and conflicts of interest among the included studies. In J. Higgins, J. Thomas, J. Chandler, M. Cumpston, T. Li, M. Page, \& V. Welch (Eds.), Cochrane Handbook for Systematic Reviews of Interventions (Draft version ed.). London: Cochrane.

Brady, C. M., DasGupta, R., Dalton, C., Wiseman, O. J., Berkley, K. J., \& Fowler, C. J. (2004). An open-label pilot study of cannabis-based extracts for bladder dysfunction in advanced multiple sclerosis. Multiple Sclerosis, 10(4), 425-433. doi:10.1191/1352458504ms1063oa

Brandt, J., \& Benedict, R. (2001). Hopkins Verbal Learning Test-Revised (HVLT-R) Psychological Assessment Resources. Lutz, FL, USA.

Campos, A. C., Moreira, F. A., Gomes, F. V., Del Bel, E. A., \& Guimaraes, F. S. (2012). Multiple mechanisms involved in the large-spectrum therapeutic potential of cannabidiol in psychiatric disorders. Philosophical Transactions of the Royal Society B: Biological Sciences, 367(1607), 3364-3378. doi:10.1098/rstb.2011.0389 
Carlini, E. A., Karniol, I. G., Renault, P. F., \& Schuster, C. R. (1974). Effects of marihuana in laboratory animals and in man. British Journal of Pharmacology, 50(2), 299-309. doi:10.1111/j.1476-5381.1974.tb08576.x

Chandra, S., Radwan, M. M., Majumdar, C. G., Church, J. C., Freeman, T. P., \& ElSohly, M. A. (2019). New trends in cannabis potency in USA and Europe during the last decade (2008-2017). European Archives of Psychiatry Clinical Neuroscience, 269(1), 5-15. doi:10.1007/s00406-019-00983-5

Colizzi, M., \& Bhattacharyya, S. (2017). Does cannabis composition matter? Differential effects of delta-9-tetrahydrocannabinol and cannabidiol on human cognition. Current Addiction Reports, 4(2), 62-74. doi:10.1007/s40429-017$0142-2$

Colizzi, M., \& Bhattacharyya, S. (2018). Cannabis use and the development of tolerance: a systematic review of human evidence. Neuroscience and Biobehavioral Reviews, 93, 1-25. doi:10.1016/j.neubiorev.2018.07.014

Cooper, Z. D., \& Haney, M. (2014). Investigation of sex-dependent effects of cannabis in daily cannabis smokers. Drug and Alcohol Dependence, 136, 85-91. doi:10.1016/j.drugalcdep.2013.12.013

Crippa, J. A. S., Derenusson, G. N., Ferrari, T. B., Wichert-Ana, L., Duran, F. L., Martin-Santos, R., . . Hallak, J. E. C. (2011). Neural basis of anxiolytic effects of cannabidiol (CBD) in generalized social anxiety disorder: A preliminary report. Journal of Psychopharmacology, 25(1), 121-130. doi:10.1177/0269881110379283

Curran, H. V., Brignell, C., Fletcher, S., Middleton, P., \& Henry, J. (2002). Cognitive and subjective dose-response effects of acute oral $\Delta 9$-tetrahydrocannabinol 
(THC) in infrequent cannabis users. Psychopharmacology, 164(1), 61-70. doi:10.1007/s00213-002-1169-0

Curran, H. V., Freeman, T. P., Mokrysz, C., Lewis, D. A., Morgan, C. J. A., \& Parsons, L. H. (2016). Keep off the grass? Cannabis, cognition and addiction. Nature Reviews Neuroscience, 17(5), 293-306. doi:10.1038/nrn.2016.28

Curran, H. V., Hindocha, C., Morgan, C. J., Shaban, N., Das, R. K., \& Freeman, T. P. (2018). Which biological and self-report measures of cannabis use predict cannabis dependency and acute psychotic-like effects? Psychological Medicine, 1-7. doi:10.1017/S003329171800226X

Curran, H. V., \& Morgan, C. J. A. (2014). Desired and undesired effects of cannabis on the human mind and psychological well-being. Handbook of Cannabis. Oxford, UK: Oxford University Press UK, 647-660.

D'Souza, D. C., Perry, E., MacDougall, L., Ammerman, Y., Cooper, T., Braley, G., . . . Krystal, J. H. (2004). The psychotomimetic effects of intravenous delta-9tetrahydrocannabinol in healthy individuals: implications for psychosis. Neuropsychopharmacology, 29(8), 1558. doi:10.1038/sj.npp.1300496

D’Souza, D. C., Ranganathan, M., Braley, G., Gueorguieva, R., Zimolo, Z., Cooper, T., . . Krystal, J. (2008). Blunted psychotomimetic and amnestic effects of $\Delta$ 9-tetrahydrocannabinol in frequent users of cannabis. Neuropsychopharmacology, 33(10), 2505-2516. doi:10.1038/sj.npp.1301643

Dalton, W. S., Martz, R., Lemberger, L., Rodda, B. E., \& Forney, R. B. (1976). Influence of cannabidiol on delta-9-tetrahydrocannabinol effects. Clinical Pharmacology \& Therapeutics, 19(3), 300-309. doi:10.1002/cpt1976193300

Demirakca, T., Sartorius, A., Ende, G., Meyer, N., Welzel, H., Skopp, G., . . . Hermann, D. (2011). Diminished gray matter in the hippocampus of cannabis 
users: Possible protective effects of cannabidiol. Drug and Alcohol Dependence, 114(2-3), 242-245. doi:10.1016/j.drugalcdep.2010.09.020

Desrosiers, N. A. (2015). Pharmacodynamics, pharmacokinetics, and cannabinoid stability following smoked cannabis in occasional and frequent cannabis smokers. Dissertation Abstracts International: Section B: The Sciences and Engineering, $76(6-\mathrm{B}(\mathrm{E}))$, No Pagination Specified. Retrieved from http://ovidsp.ovid.com/ovidweb.cgi?T=JS\&CSC=Y\&NEWS=N\&PAGE=full $\underline{\text { text } \& D=p s y c 12 \& A N=2015-99240-307}$

https://ucl-new-

primo.hosted.exlibrisgroup.com/openurl/UCL/UCL_VU2?sid=OVID:psycdb

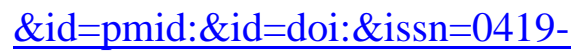

$\underline{4217 \& \text { isbn }=9781321493177 \& \text { volume }=76 \& \text { issue }=6-}$

$\underline{\mathrm{B} \% 28 \mathrm{E} \% 29 \& \text { spage }=\text { No\&pages }=\mathrm{No}+\text { Pagination }+ \text { Specified } \& \text { date }=2015 \& \text { title }}$ $=$ Dissertation + Abstracts + International\%3A + Section $+\mathrm{B} \% 3 \mathrm{~A}+\mathrm{The}+$ Sciences + $\underline{\text { and }+ \text { Engineering \&atitle }=\mathrm{Pharmacod} \text { nnamics } \% 2 \mathrm{C}+\text { pharmacokinetics } \% 2 \mathrm{C}+\mathrm{an}}$ $\underline{\mathrm{d}+\text { cannabinoid }+ \text { stability }+ \text { following }+ \text { smoked+cannabis }+\mathrm{in}+\text { occasional }+ \text { and }+\mathrm{f}}$ $\underline{\text { requent+cannabis+smokers.\&aulast=Desrosiers }}$

Doss, M. K., Weafer, J., Ruiz, N. A., Gallo, D. A., \& De Wit, H. (2018). Alcohol and pharmacologically similar sedatives impair encoding and facilitate consolidation of both recollection and familiarity in episodic memory. Cognitive neuroscience, 9(3-4), 89-99.

Efron, D., \& Freeman, J. (2018). Medical cannabis for paediatric developmentalbehavioural and psychiatric disorders. Journal of Paediatrics and Child Health, 54(7), 715-717. Retrieved from 
http://ovidsp.ovid.com/ovidweb.cgi?T=JS\&CSC=Y\&NEWS=N\&PAGE=full $\underline{\text { text } \& D=e m e x a \& A N=621550423}$

https://ucl-new-

primo.hosted.exlibrisgroup.com/openurl/UCL/UCL_VU2?sid=OVID:embase

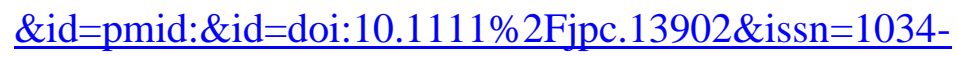

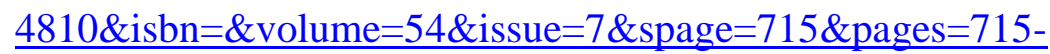

$\underline{717 \& \text { date }=2018 \& \text { title }=\text { Journal }+ \text { of }+ \text { Paediatrics }+ \text { and }+ \text { Child }+ \text { Health \&atitle }=\mathrm{M}}$ $\underline{\text { edical+cannabis+for+paediatric+developmental- }}$ behavioural+and + psychiatric + disorders\&aulast $=$ Efron

Englund, A., Freeman, T. P., Murray, R. M., \& McGuire, P. (2017). Can we make cannabis safer? The Lancet Psychiatry, 4(8), 643-648. doi:10.1016/S22150366(17)30075-5

Englund, A., Morrison, P. D., Nottage, J., Hague, D., Kane, F., Bonaccorso, S., . . . Bonaccorso, S. (2013). Cannabidiol inhibits THC-elicited paranoid symptoms and hippocampal-dependent memory impairment. Journal of Psychopharmacology, 27(1), 19-27. doi:10.1177/0269881112460109

Evans, M. A., Martz, R., Brown, D. J., Rodda, B. E., Kiplinger, G. F., Lemberger, L., \& Forney, R. B. (1973). Impairment of performance with low doses of marihuana. Clinical Pharmacology \& Therapeutics, 14(6), 936-940. doi:10.1002/cpt1973146936

Freeman, A. M., Lees, R., Petrilli, K., Saunders, R., Hindocha, C., Mokrysz, C., . . Curran, H. V. (2019). How does cannabidiol (CBD) influence the acute effects of delta-9- tetrahydrocannabinol ( $\triangle 9-T H C)$ in humans? A systematic review. . Retrieved from PROSPERO: 
http://www.crd.york.ac.uk/PROSPERO/display_record.php?ID=CRD420191 $\underline{26994}$

Freeman, D., Pugh, K., Green, C., Valmaggia, L., Dunn, G., \& Garety, P. (2007). A measure of state persecutory ideation for experimental studies. The Journal of $\begin{array}{llll}\text { Nervous } \quad \text { and } & \text { Mental }\end{array}$ doi:10.1097/NMD.0b013e318145a0a9

Freeman, T. P., Groshkova, T., Cunningham, A., Sedefov, R., Griffiths, P., \& Lynskey, M. T. (2018). Increasing potency and price of cannabis in Europe, 2006-16. Addiction, 114(6), 1015-1023. doi:10.1111/add.14525

Freeman, T. P., Hindocha, C., Green, S. F., \& Bloomfield, M. A. P. (2019). Medicinal use of cannabis based products and cannabinoids. British Medical Journal, 365, 1141. doi:10.1136/bmj.11141

Freeman, T. P., \& Lorenzetti, V. (in press). Standard THC Units': a proposal to standardise dose across all cannabis products and methods of administration. . Addiction.

Freeman, T. P., Morgan, C. J. A., Hindocha, C., Schafer, G., Das, R. K., \& Curran, H. V. (2014). Just say 'know': how do cannabinoid concentrations influence users' estimates of cannabis potency and the amount they roll in joints? Addiction, 109(10), 1686-1694. doi:10.1111/add.12634

Freeman, T. P., Pope, R. A., Wall, M. B., Bisby, J. A., Luijten, M., Hindocha, C., . . . Curran, H. V. (2018). Cannabis Dampens the Effects of Music in Brain Regions Sensitive to Reward and Emotion. International Journal of Neuropsychopharmacology, 21(1), 21-32. doi:10.1093/ijnp/pyx082 
Gaoni, Y., \& Mechoulam, R. (1964). Isolation, structure, and partial synthesis of an active constituent of hashish. Journal of the American Chemical Society, 86(8), 1646-1647. doi:10.1021/ja01062a046

Green, B., Kavanagh, D., \& Young, R. (2003). Being stoned: a review of self-reported cannabis effects. Drug and Alcohol Review, 22(4), 453-460. doi:doi:10.1080/09595230310001613976

Guy, G. W., \& Flint, M. E. (2003). A single centre, placebo-controlled, four period, crossover, tolerability study assessing, pharmacodynamic effects, pharmacokinetic characteristics and cognitive profiles of a single dose of three formulations of cannabis based medicine extracts (CBMEs) (GWPD9901), plus a two period tolerability study comparing pharmacodynamic effects and pharmacokinetic characteristics of a single dose of a cannabis based medicine extract given via two administration routes (GWPD9902 EXT). Journal of Cannabis Therapeutics, 3(3), 35-77. doi:10.1300/J175v03n03_03

Guy, G. W., \& Robson, P. J. (2003). A phase I, double blind, three-way crossover study to assess the pharmacokinetic profile of cannabis based medicine extract (CBME) administered sublingually in variant cannabinoid ratios in normal healthy male volunteers (GWPK0215). Journal of Cannabis Therapeutics, 3(4), 121-152. doi:10.1300/J175v03n04_02

Guy, G. W., \& Robson, P. J. (2004). A Phase I, open label, four-way crossover study to compare the pharmacokinetic profiles of a single dose of $20 \mathrm{mg}$ of a cannabis based medicine extract (CBME) administered on 3 different areas of the buccal mucosa and to investigate the pharmacokinetics of CBME per oral in healthy male and female volunteers (GWPK0112). Journal of Cannabis Therapeutics, 3(4), 79-120. doi:10.1300/J175v03n04_01 
Hall, W., Hoch, E., \& Lorenzetti, V. (2019). Cannabis use and mental health: risks and benefits. European Archives of Psychiatry and Clinical Neuroscience, 269(1), 1-3. doi:10.1007/s00406-019-00986-2

Haney, M., Malcolm, R. J., Babalonis, S., Nuzzo, P. A., Cooper, Z. D., Bedi, G., . . . Walsh, S. L. (2016). Oral cannabidiol does not alter the subjective, reinforcing or cardiovascular effects of smoked cannabis. Neuropsychopharmacology, 41(8), 1974-1982. doi:10.1038/npp.2015.367

Hanuš, L. O., Meyer, S. M., Muñoz, E., Taglialatela-Scafati, O., \& Appendino, G. (2016). Phytocannabinoids: a unified critical inventory. Natural Product Reports, 33(12), 1357-1392. doi:10.1039/c6np00074f

Hayakawa, K., Mishima, K., Hazekawa, M., Sano, K., Irie, K., Orito, K., . . Fujiwara, M. (2008). Cannabidiol potentiates pharmacological effects of $\Delta 9$ tetrahydrocannabinol via $\mathrm{CB} 1$ receptor-dependent mechanism. Brain Research, 1188, 157-164. doi:10.1016/j.brainres.2007.09.090

Herrmann, E. S., Cone, E. J., Mitchell, J. M., Bigelow, G. E., LoDico, C., Flegel, R., . .. dependence, a. (2015). Non-smoker exposure to secondhand cannabis smoke II: Effect of room ventilation on the physiological, subjective, and behavioral/cognitive effects. 151, 194-202.

Higgins, J. P., Altman, D. G., Gøtzsche, P. C., Jüni, P., Moher, D., Oxman, A. D., . . Sterne, J. A. (2011). The Cochrane Collaboration's tool for assessing risk of bias in randomised trials. British Medical Journal, 343, d5928. doi:10.1136/bmj.d5928

Higgins, J. P., \& Green, S. (2008). Cochrane handbook for systematic reviews of interventions (Version 5.1.0 [updated March 2011] ed.): The Cochrane Collaboration. 
Higgins, J. P., Sterne, J., Savović, J., Page, M., Hróbjartsson, A., Boutron, I., . . . Eldridge, S. (2016). A revised tool for assessing risk of bias in randomized trials. In J. Chandler, J. McKenzie, I. Boutron, \& V. Welch (Eds.), Cochrane Database Systematic Reviews (Vol. 10, pp. 29-31): Cochrane Methods.

Hindocha, C., Freeman, T. P., Schafer, G., Gardener, C., Das, R. K., Morgan, C. J. A., \& Curran, H. V. (2015). Acute effects of delta-9-tetrahydrocannabinol, cannabidiol and their combination on facial emotion recognition: A randomised, double-blind, placebo-controlled study in cannabis users. European Neuropsychopharmacology, 25(3), 325-334. doi:10.1016/j.euroneuro.2014.11.014

Hindocha, C., Freeman, T. P., Schafer, G., Gardner, C., Bloomfield, M. A. P., Bramon, E., . . . Curran, H. V. (2019). Acute effects of cannabinoids on addiction endophenotypes are moderated by genes encoding the CB1 receptor and FAAH enzyme. Addiction Biology, e12762. doi:10.1111/adb.12762

Hollister, L. E. (1973). Cannabidiol and cannabinol in man. Experientia, 29(7), 825826. doi:10.1007/bf01946311

Hollister, L. E., \& Gillespie, H. (1975). Interactions in man of delta-9tetrahydrocannabinol. II. Cannabinol and cannabidiol. Clinical Pharmacology \& Therapeutics, 18(1), 80-83. doi:10.1002/cpt197518180

Hunault, C. C., Mensinga, T. T., Böcker, K. B., Schipper, C. M. A., Kruidenier, M., Leenders, M. E., . . Meulenbelt, J. (2009). Cognitive and psychomotor effects in males after smoking a combination of tobacco and cannabis containing up to $69 \mathrm{mg}$ delta-9-tetrahydrocannabinol (THC). Psychopharmacology, 204(1), 85-94. doi:10.1007/s00213-008-1440-0 
Hundal, H., Lister, R., Evans, N., Antley, A., Englund, A., Murray, R. M., . . . Morrison, P. D. (2018). The effects of cannabidiol on persecutory ideation and anxiety in a high trait paranoid group. Jourbal od Psychopharmacology, 32(3), 276-282. doi:10.1177/0269881117737400

Hunt, C. A., Jones, R. T., Herning, R. I., \& Bachman, J. (1981). Evidence that cannabidiol does not significantly alter the pharmacokinetics of tetrahydrocannabinol in man. Journal of Pharmacokinetics \& Biopharmaceutics, 9(3), 245-260. doi:10.1007/BF01059266

Ilan, A. B., Gevins, A., Coleman, M., ElSohly, M. A., \& de Wit, H. (2005). Neurophysiological and subjective profile of marijuana with varying concentrations of cannabinoids. Behavioural Pharmacology, 16(5-6), 487-496. doi:10.1097/00008877-200509000-00023

Iseger, T. A., \& Bossong, M. G. (2015). A systematic review of the antipsychotic properties of cannabidiol in humans. Schizophrenia Research, 162(1-3), 153161. doi:10.1016/j.schres.2015.01.033

Jadoon, K. A., Tan, G. D., \& O'Sullivan, S. E. (2017). A single dose of cannabidiol reduces blood pressure in healthy volunteers in a randomized crossover study. JCI insight, 2(12), e93760. doi:10.1172/jci.insight.93760

Javitt, D. C., Doneshka, P., Grochowski, S., \& Ritter, W. (1995). Impaired mismatch negativity generation reflects widespread dysfunction of working memory in schizophrenia. Archives of General Psychiatry, 52(7), 550-558. doi:10.1001/archpsyc.1995.03950190032005

Johnson, J. R., Burnell-Nugent, M., Lossignol, D., Ganae-Motan, E. D., Potts, R., \& Fallon, M. T. (2010). Multicenter, double-blind, randomized, placebocontrolled, parallel-group study of the efficacy, safety, and tolerability of 
THC:CBD extract and THC extract in patients with intractable cancer-related pain. Journal of Pain \& Symptom Management, 39(2), 167-179. doi:10.1016/j.jpainsymman.2009.06.008

Juckel, G., Roser, P., Nadulski, T., Stadelmann, A. M., \& Gallinat, J. (2007). Acute effects of $\Delta 9$-tetrahydrocannabinol and standardized cannabis extract on the auditory evoked mismatch negativity. Schizophrenia Research, 97(1-3), 109117. doi:10.1016/j.schres.2007.08.015

Karniol, I. G., \& Carlini, E. A. (1973). Comparative Studies in Man and in Laboratory Animals on $\Delta 8$-and $\Delta$ 9-trans-Tetrahydrocannabinol. Pharmacology and Therapeutics, 9(2), 115-126. doi:10.1159/000136375

Karniol, I. G., \& Carlini, E. A. (1974). Pharmacological interaction between cannabidiol and delta 9-tetrahydrocannabinol. Psychopharmacologia, 33(1), 53-70. doi:10.1007/BF00428793

Karniol, I. G., Shirakawa, I., Kasinski, N., Pfeferman, A., \& Carlini, E. A. (1974). Cannabidiol interferes with the effects of $\Delta 9$-tetrahydrocannabinol in man. European journal of pharmacology, 28(1), 172-177. doi:10.1016/00142999(74)90129-0

Karschner, E. L., Darwin, W. D., McMahon, R. P., Liu, F., Wright, S., Goodwin, R. S., \& Huestis, M. A. (2011). Subjective and physiological effects after controlled Sativex and oral THC administration. Clinical Pharmacology \& Therapeutics, 89(3), 400-407. doi:10.1038/clpt.2010.318

Katona, I., \& Freund, T. F. (2012). Multiple functions of endocannabinoid signaling in the brain. Annual Review of Neuroscience, 35, 529-558. doi:10.1146/annurev-neuro-062111-150420 
Kay, S. R., Fiszbein, A., \& Opler, L. A. (1987). The positive and negative syndrome scale (PANSS) for schizophrenia. Schizophrenia Bulletin, 13(2), 261-276. doi:10.1093/schbul/13.2.261

Khoury, J. M., Neves, M. d. C. L. d., Roque, M. A. V., Queiroz, D. A. d. B., Corrêa de Freitas, A. A., de Fátima, Â., . . Garcia, F. D. (2019). Is there a role for cannabidiol in psychiatry? The World Journal of Biological Psychiatry, 20(2), 101-116. doi:10.1080/15622975.2017.1285049

Kilmer, B. (2017). New developments in cannabis regulation. Retrieved from Lisbon: Portugal:

$\underline{\text { www.emcdda.europa.eu/system/files/attachments/6232/EuropeanResponsesG }}$ uide2017_BackgroundPaper-Cannabis-policy_0.pdf

Kirchner, W. K. (1958). Age differences in short-term retention of rapidly changing information. Journal of Experimental Psychology, 55(4), 352-358. doi:10.1037/h0043688

Kleykamp, B. A., Griffiths, R. R., \& Mintzer, M. Z. (2010). Dose effects of triazolam and alcohol on cognitive performance in healthy volunteers. Experimental Clinical Psychopharmacology, 18(1), 1-16. doi:10.1037/a0018407

Klumpers, L. E., Cole, D. M., Khalili-Mahani, N., Soeter, R. P., te Beek, E. T., Rombouts, S. A., \& van Gerven, J. M. (2012). Manipulating brain connectivity with 89 -tetrahydrocannabinol: a pharmacological resting state FMRI study. Neuroimage, 63(3), 1701-1711. doi:10.1016/j.neuroimage.2012.07.051

Kowal, M. A., Hazekamp, A., Colzato, L. S., van Steenbergen, H., van der Wee, N. J., Durieux, J., . . . Hommel, B. (2015). Cannabis and creativity: highly potent cannabis impairs divergent thinking in regular cannabis users. Psychopharmacology, 232(6), 1123-1134. 
Laprairie, R. B., Bagher, A. M., Kelly, M. E. M., \& Denovan-Wright, E. M. (2015). Cannabidiol is a negative allosteric modulator of the cannabinoid CB1 receptor. British Journal of Pharmacology, 172(20), 4790-4805. doi:10.1111/bph.13250

Lawn, W., Freeman, T. P., Pope, R. A., Joye, A., Harvey, L., Hindocha, C., . . Curran, H. V. (2016). Acute and chronic effects of cannabinoids on effort-related decision-making and reward learning: an evaluation of the cannabis 'amotivational' hypotheses. Psychopharmacology, 233(19-20), 3537-3552. doi:10.1007/s00213-016-4383-x

Lee, D., Karschner, E. L., Milman, G., Barnes, A. J., Goodwin, R. S., \& Huestis, M. A. (2013). Can oral fluid cannabinoid testing monitor medication compliance and/or cannabis smoking during oral THC and oromucosal Sativex administration? Drug \& Alcohol Dependence, 130(1-3), 68-76. doi:10.1016/j.drugalcdep.2012.10.011

Leweke, F., Schneider, U., Radwan, M., Schmidt, E., \& Emrich, H. M. (2000). Different Effects of Nabilone and Cannabidiol on Binocular Depth Inversion in Man. Pharmacology Biochemistry and Behavior, 66(1), 175-181. doi:10.1016/S0091-3057(00)00201-X

Lewis, P. A., \& Miall, R. C. (2006). Remembering the time: a continuous clock. Trends in Cognitive Sciences, 10(9), 401-406. doi:10.1016/j.tics.2006.07.006

Liberati, A., Altman, D. G., Tetzlaff, J., Mulrow, C., Gøtzsche, P. C., Ioannidis, J. P., ... Moher, D. (2009). The PRISMA statement for reporting systematic reviews and meta-analyses of studies that evaluate health care interventions: explanation and elaboration. PLoS medicine, 6(7), e1000100. doi:journal.pmed.1000100 
Lu, H.-C., \& Mackie, K. (2016). An introduction to the endogenous cannabinoid $\begin{array}{llll}\text { system. } & \text { Biological } & \text { 59ychiatry, } & \text { 59(7), }\end{array}$ doi:10.1016/j.biopsych.2015.07.028

Lucas, C. J., Galettis, P., \& Schneider, J. (2018). The pharmacokinetics and the pharmacodynamics of cannabinoids. $84(11), \quad 2477-2482$. doi:10.1111/bcp.13710

Machin, D., Campbell, M. J., Tan, S. B., \& Tan, S. H. (2018). Sample Sizes for Clinical, Laboratory and Epidemiology Studies (4 ed.). Oxford, UK: WileyBlackwell.

Mason, O. J., Morgan, C. J. A., Dhiman, S., Patel, A., Parti, N., \& Curran, H. V. (2009). Acute cannabis use causes increased psychotomimetic experiences in individuals prone to psychosis. Psychological Medicine, 39(6), 951-956. doi:10.1017/S0033291708004741

Mason, O. J., Morgan, C. J. A., Stefanovic, A., \& Curran, H. V. (2008). The psychotomimetic states inventory (PSI): measuring psychotic-type experiences from ketamine and cannabis. Schizophrenia Research, 103(1-3), 138-142. doi:10.1016/j.schres.2008.02.020

Mayor, S. (2019). WHO proposes rescheduling cannabis to allow medical applications. British Medical Journal, 364, 574. doi:10.1136/bmj.1574

McLeod, D. R., Griffiths, R. R., Bigelow, G. E., \& Yingling, J. (1982). An automated version of the digit symbol substitution test (DSST). Behavior Research Methods and Instrumentation, 14(5), 463-466. doi:10.3758/BF03203313

McPartland, J. M., \& Russo, E. B. (2014). Non-phytocannabinoid constituents of cannabis and herbal synergy. In R. G. Pertwee (Ed.), Handbook of cannabis (pp. 280-295). Oxford, UK: Oxford University Press UK. 
Mechoulam, R., Parker, L. A., \& Gallily, R. (2002). Cannabidiol: an overview of some pharmacological aspects. The Journal of Clinical Pharmacology, 42(S1), 11S19S.

Moher, D., Liberati, A., Tetzlaff, J., Altman, D. G., \& Group, P. (2009). Preferred reporting items for systematic reviews and meta-analyses: the PRISMA $\begin{array}{llll}\text { statement. } & \text { PLoS } & \text { 6(7), } & \text { medicine, }\end{array}$ doi:10.1371/journal.pmed.1000097

Morgan, C. J. A., \& Curran, H. V. (2008). Effects of cannabidiol on schizophrenialike symptoms in people who use cannabis. The British Journal of Psychiatry, 192(4), 306-307. doi:10.1192/bjp.bp.107.046649

Morgan, C. J. A., Freeman, T. P., Hindocha, C., Schafer, G., Gardner, C., \& Curran, H. V. (2018). Individual and combined effects of acute delta-9tetrahydrocannabinol and cannabidiol on psychotomimetic symptoms and memory function. Translational Psychiatry, 8 (181). doi:10.1038/s41398-0180191-x

Morgan, C. J. A., Freeman, T. P., Powell, J., \& Curran, H. V. (2016). AKT1 genotype moderates the acute psychotomimetic effects of naturalistically smoked cannabis in young cannabis smokers. Translational Psychiatry, 6(2), e738. doi:10.1038/tp.2015.219

Morgan, C. J. A., Freeman, T. P., Schafer, G. L., \& Curran, H. V. (2010). Cannabidiol attenuates the appetitive effects of $\Delta$ 9-tetrahydrocannabinol in humans smoking their chosen cannabis. Neuropsychopharmacology, 35(9), 1879.

Morgan, C. J. A., Gardener, C., Schafer, G., Swan, S., Demarchi, C., Freeman, T. P., . . Curran, H. V. (2011). Sub-chronic impact of cannabinoids in street cannabis 
on cognition, psychotic-like symptoms and psychological well-being. Psychological Medicine, 42(2), 391-400. doi:10.1017/S0033291711001322

Morgan, C. J. A., Schafer, G., Freeman, T. P., \& Curran, H. V. (2010). Impact of cannabidiol on the acute and psychotomimetic effects of smoked cannabis: naturalistic study. British Journal of Psychiatry, 197(4), 285-290. doi:10.1192/bjp.bp.110.077503

Morrison, P., \& Stone, J. (2011). Synthetic delta-9-tetrahydrocannabinol elicits schizophrenia-like negative symptoms which are distinct from sedation. Human Psychopharmacology: Clinical and Experimental, 26(1), 77-80. doi:10.1002/hup.1166

Morrison, P., Zois, V., McKeown, D., Lee, T., Holt, D., Powell, J., . . Murray, R. (2009). The acute effects of synthetic intravenous $\Delta 9$-tetrahydrocannabinol on psychosis, mood and cognitive functioning. Psychological Medicine, 39(10), 1607-1616. doi:10.1017/S0033291709005522

Nadulski, T., Pragst, F., Weinberg, G., Roser, P., Schnelle, M., Fronk, E. M., \& Stadelmann, A. M. (2005). Randomized, double-blind, placebo-controlled study about the effects of cannabidiol (CBD) on the pharmacokinetics of Delta9-tetrahydrocannabinol (THC) after oral application of THC verses standardized cannabis extract. Therapeutic Drug Monitoring, 27(6), 799-810. doi:10.1097/01.ftd.0000177223.19294.5c

Nicholson, A. N., Turner, C., Stone, B. M., \& Robson, P. J. (2004). Effect of DELTA9-Tetrahydrocannabinol and Cannabidiol on Nocturnal Sleep and EarlyMorning Behavior in Young Adults. Journal of Clinical Psychopharmacology, 24(3), 305-313. doi:10.1097/01.jcp.0000125688.05091.8f 
Niesink, R. J., \& van Laar, M. W. (2013). Does cannabidiol protect against adverse psychological effects of THC? Frontiers in Psychiatry, 4(130). doi:10.3389/fpsyt.2013.00130

Notcutt, W., Price, M., Miller, R., Newport, S., Phillips, C., Simmons, S., \& Sansom, C. (2004). Initial experiences with medicinal extracts of cannabis for chronic pain: results from 34 'N of 1' studies. Anaesthesia, 59(5), 440-452. doi:10.1111/j.1365-2044.2004.03674.x

Nutt, D. (2015). Illegal drugs laws: clearing a 50-year-old obstacle to research. PLoS biology, 13(1), e1002047-e1002047. doi:10.1371/journal.pbio.1002047

Overall, J. E., \& Gorham, D. R. (1962). The brief psychiatric rating scale. Psychological Reports, 10(3), 799-812. doi:10.2466/pr0.1962.10.3.799

Paton, W. D. M., \& Pertwee, R. G. (1972). Effect of cannabis and certain of its constituents on pentobarbitone sleeping time and phenazone metabolism. British Journal of Pharmacology, 44(2), 250-261. doi:10.1111/j.14765381.1972.tb07261.x

Perez-Reyes, M., Timmons, M. C., Davis, K., \& Wall, E. (1973). A comparison of the pharmacological activity in man of intravenously administered 1368-1136811368-1, cannabinol, and cannabidiol. Experientia, 29(11), 1368-1369. doi:10.1007/BF01922823

Perry, D., Ton, J., \& Allan, G. M. (2018). Evidence for THC versus CBD in cannabinoids. Canadian Family Physician, 64(8), 519-519. Retrieved from http://search.ebscohost.com/login.aspx $?$ direct=true\&AuthType $=i p, \operatorname{shib} \& d b=j$ $\underline{\text { lh\&AN }=131282265 \& \text { site }=\text { ehost-live } \& \text { scope }=\text { site }}$ 
Pertwee, R. G. (2008). The diverse CB1 and CB2 receptor pharmacology of three plant cannabinoids: $\quad \Delta$ 9-tetrahydrocannabinol, cannabidiol and $\Delta 9$ tetrahydrocannabivarin. 153(2), 199-215. doi:10.1038/sj.bjp.0707442

Pertwee, R. G., \& Cascio, M. G. (2014). Known pharmacological actions of delta-9tetrahydrocannabinol and of four other chemical constituents of cannabis that activate cannabinoid receptors. In R. G. Pertwee (Ed.), Handbook of Cannabis (pp. 115). Oxford, UK: Oxford University Press.

Potter, D. J., Hammond, K., Tuffnell, S., Walker, C., \& Di Forti, M. (2018). Potency of $\Delta 9$-tetrahydrocannabinol and other cannabinoids in cannabis in England in 2016: Implications for public health and pharmacology. Drug Testing Analysis, 10(4), 628-635. doi:10.1002/dta.2368

Ranganathan, M., \& D'Souza, D. C. (2006). The acute effects of cannabinoids on memory in humans: a review. Psychopharmacology, 188(4), 425-444. doi:10.1007/s00213-006-0508-y

Ranganathan, M., Radhakrishnan, R., Addy, P. H., Schnakenberg-Martin, A. M., Williams, A. H., Carbuto, M., . . Skosnik, P. D. (2017). Tetrahydrocannabinol (THC) impairs encoding but not retrieval of verbal information. Progress in Neuro-Psychopharmacology and Biological Psychiatry, 79, 176-183.

Roser, P., Gallinat, J., Weinberg, G., Juckel, G., Gorynia, I., \& Stadelmann, A. M. (2009). Psychomotor performance in relation to acute oral administration of DELTA9-tetrahydrocannabinol and standardized cannabis extract in healthy human subjects. European Archives of Psychiatry and Clinical Neuroscience, 259(5), 284-292. doi:10.1007/s00406-009-0868-5

Roser, P., Juckel, G., Rentzsch, J., Nadulski, T., Gallinat, J., \& Stadelmann, A. M. (2008). Effects of acute oral delta9-tetrahydrocannabinol and standardized 
cannabis extract on the auditory p300 event-related potential in healthy volunteers. European Neuropsychopharmacology, 18(8), 569-577. doi:10.1016/j.euroneuro.2008.04.008

Ross, R. A. (2007). Allosterism and cannabinoid CB1 receptors: the shape of things to come. Trends in Pharmacological Sciences, 28(11), 567-572. doi:10.1016/j.tips.2007.10.006

Russo, E. B. (2011). Taming THC: potential cannabis synergy and phytocannabinoidterpenoid entourage effects. British Journal of Pharmacology, 163(7), 13441364. doi:10.1111/j.1476-5381.2011.01238.x

Russo, E. B. (2019). The Case for the Entourage Effect and Conventional Breeding of Clinical Cannabis: No “Strain,” No Gain. Frontiers in Plant Science, 9(1969). doi:10.3389/fpls.2018.01969

Russo, E. B., Burnett, A., Hall, B., \& Parker, K. K. (2005). Agonistic properties of cannabidiol at 5-HT1a receptors. Neurochemical research, 30(8), 1037-1043. doi:10.1007/s11064-005-6978-1

Russo, E. B., \& Guy, G. W. (2006). A tale of two cannabinoids: the therapeutic rationale for combining tetrahydrocannabinol and cannabidiol. Medical Hypotheses, 66(2), 234-246. doi:10.1016/j.mehy.2005.08.026

Russo, E. B., \& McPartland, J. M. (2003). Cannabis is more than simply $\Delta$ 9tetrahydrocannabinol. Psychopharmacology, 165(4), 431-432. doi:10.1007/s00213-002-1348-z

Ryberg, E., Larsson, N., Sjögren, S., Hjorth, S., Hermansson, N. O., Leonova, J., . . . Greasley, P. (2007). The orphan receptor GPR55 is a novel cannabinoid receptor. British Journal of Pharmacology, 152(7), 1092-1101. doi:10.1038/sj.bjp.0707460 
Schoedel, K. A., Chen, N., Hilliard, A., White, L., Stott, C., Russo, E., . . Sellers, E. M. (2011). A randomized, double-blind, placebo-controlled, crossover study to evaluate the subjective abuse potential and cognitive effects of nabiximols oromucosal spray in subjects with a history of recreational cannabis use. Human Psychopharmacology: Clinical and Experimental, 26(3), 224-236. doi:10.1002/hup.1196

Schoeler, T., \& Bhattacharyya, S. (2013). The effect of cannabis use on memory function: an update. Subst Abuse Rehabil, 4, 11-27. doi:10.2147/sar.S25869

Schubart, C. D., Sommer, I. E., van Gastel, W. A., Goetgebuer, R. L., Kahn, R. S., Boks, M. P., . . . Boks, M. P. M. (2011). Cannabis with high cannabidiol content is associated with fewer psychotic experiences. Schizophrenia Research, 130(1-3), 216-221. doi:10.1016/j.schres.2011.04.017

Sedgwick, P. (2015). Bias in randomised controlled trials: comparison of crossover group and parallel group designs. 351, h4283. doi:10.1136/bmj.h4283 \%J BMJ : British Medical Journal

Seeley, W. W., Menon, V., Schatzberg, A. F., Keller, J., Glover, G. H., Kenna, H., . . . Greicius, M. D. (2007). Dissociable intrinsic connectivity networks for salience processing and executive control. Journal of Neuroscience, 27(9), 2349-2356. doi:10.1523/JNEUROSCI.5587-06.2007

Simmons, J. P., Nelson, L. D., \& Simonsohn, U. (2011). False-positive psychology: Undisclosed flexibility in data collection and analysis allows presenting anything as significant. Psychological science, 22(11), 1359-1366. doi:10.1177/0956797611417632

Solowij, N., Broyd, S., Greenwood, L. M., van Hell, H., Martelozzo, D., Rueb, K., . . - Martin, J. (2019). A randomised controlled trial of vaporised $\Delta$ 9- 
tetrahydrocannabinol and cannabidiol alone and in combination in frequent and infrequent cannabis users: acute intoxication effects. European Archives of Psychiatry and Clinical Neuroscience, 1-19. doi:10.1007/s00406-019-009782

Spielberger, C. D. (2010). State-Trait Anxiety Inventory (2nd ed.). Palo Alto, CA: Consulting Psychologists Press.

Stadelmann, A. M., Juckel, G., Arning, L., Gallinat, J., Epplen, J. T., \& Roser, P. (2011). Association between a cannabinoid receptor gene (CNR1) polymorphism and cannabinoid-induced alterations of the auditory eventrelated P300 potential. Neuroscience Letters, 496(1), 60-64. doi:10.1016/j.neulet.2011.04.003

Strasser, F., Luftner, D., Possinger, K., Ernst, G., Ruhstaller, T., Meissner, W., . . Cerny, T. (2006). Comparison of orally administered cannabis extract and delta-9-tetrahydrocannabinol in treating patients with cancer-related anorexiacachexia syndrome: a multicenter, phase III, randomized, double-blind, placebo-controlled clinical trial from the Cannabis-In-Cachexia-Study-Group. Journal of Clinical Oncology, 24(21), 3394-3400. doi:10.1200/JCO.2005.05.1847

Szkudlarek, H. J., Desai, S. J., Renard, J., Pereira, B., Norris, C., Jobson, C. E., . . . Laviolette, S. R. (2019). $\Delta$-9-Tetrahydrocannabinol and cannabidiol produce dissociable effects on prefrontal cortical executive function and regulation of affective behaviors. Neuropsychopharmacology, 44(4), 817. doi:10.1038/s41386-018-0282-7

Thomas, A., Baillie, G., Phillips, A., Razdan, R., Ross, R. A., \& Pertwee, R. G. (2007). Cannabidiol displays unexpectedly high potency as an antagonist of CB1 and 
CB2 receptor agonists in vitro. British Journal of Pharmacology, 150(5), 613623. doi:10.1038/sj.bjp.0707133

Treadway, M. T., Buckholtz, J. W., Schwartzman, A. N., Lambert, W. E., \& Zald, D. H. (2009). Worth the 'EEfRT'? The effort expenditure for rewards task as an objective measure of motivation and anhedonia. PloS one, 4(8), e6598. doi:10.1371/journal.pone.0006598

Valle, M., Martial, L. C., Garrido, M., Rodríguez-Fornells, A., Puntes, M., Antonijoan, R. M., . . Riba, J. (2015). Cannabidiol attenuates the increased susceptibility to false memories produced by tetrahydrocannabinol. Drug \& Alcohol Dependence, 156, e228-e228. doi:10.1016/j.drugalcdep.2015.07.615

van de Donk, T., Niesters, M., Kowal, M. A., Olofsen, E., Dahan, A., \& van Velzen, M. (2019). An experimental randomized study on the analgesic effects of pharmaceutical-grade cannabis in chronic pain patients with fibromyalgia. Pain, 160(4), 860-869. doi:10.1097/j.pain.0000000000001464

Volkow, N. D., Swanson, J. M., Evins, A. E., DeLisi, L. E., Meier, M. H., Gonzalez, R., .. . Baler, R. (2016). Effects of cannabis use on human behavior, including cognition, motivation, and psychosis: a review. JAMA Psychiatry, 73(3), 292297. doi:10.1001/jamapsychiatry.2015.3278

Wade, D. T., Makela, P., Robson, P., House, H., \& Bateman, C. (2004). Do cannabisbased medicinal extracts have general or specific effects on symptoms in multiple sclerosis? A double-blind, randomized, placebo-controlled study on 160 patients. Multiple Sclerosis, 10(4), 434-441. doi:10.1191/1352458504ms1082oa

Wade, D. T., Robson, P., House, H., Makela, P., \& Aram, J. (2003). A preliminary controlled study to determine whether whole-plant cannabis extracts can 
improve intractable neurogenic symptoms. Clinical Rehabilitation, 17(1), 2129. doi:10.1191/0269215503cr581oa

Wall, M. B., Pope, R., Freeman, T. P., Kowalczyk, O. S., Demetriou, L., Mokrysz, C., ... Curran, H. V. (2019). Dissociable effects of cannabis with and without cannabidiol on the human brain's resting-state functional connectivity. Journal of Psychopharmacology, $\quad 0269881119841568$. doi:10.1177/0269881119841568

White, C. M. (2019). A Review of Human Studies Assessing Cannabidiol's (CBD) Therapeutic Actions and Potential. 59(7), 923-934. doi:10.1002/jcph.1387

Whiting, P. F., Wolff, R. F., Deshpande, S., Di Nisio, M., Duffy, S., Hernandez, A. V., . . Kleijnen, J. (2015). Cannabinoids for medical use: a systematic review and meta-analysis. JAMA Psychiatry, 313(24), 2456-2473. doi:10.1001/jama.2015.6358

Wilson, B., Cockburn, J., Baddeley, A., \& Hiorns, R. (1989). The development and validation of a test battery for detecting and monitoring everyday memory problems. Journal of Clinical and Experimental Neuropsychology, 11(6), 855870. doi:10.1080/01688638908400940

Yuan, J. T., Tello, T. L., Hultman, C., Barker, C. A., Arron, S. T., \& Yom, S. S. (2017). Medical marijuana for the treatment of vismodegib-related muscle spasm. JAAD Case Reports, 3(5), 438-440. doi:1016/j.jdcr.2017.06.012

Zuardi, A. W. (2008). Cannabidiol: from an inactive cannabinoid to a drug with wide spectrum of action. Brazilian Journal of Psychiatry, 30(3), 271-280. doi:10.1590/S1516-44462008000300015 
Zuardi, A. W., Guimaraes, F. S., \& Moreira, A. C. (1993). Effect of cannabidiol on plasma prolactin, growth hormone and cortisol in human volunteers. Brazilian Journal of Medical and Biological Research, 26(2), 213-217.

Zuardi, A. W., Shirakawa, I., Finkelfarb, E., \& Karniol, I. G. (1982). Action of cannabidiol on the anxiety and other effects produced by delta 9-THC in normal subjects. Psychopharmacology, 76(3), 245-250. doi:10.1007/BF00432554

Zuurman, L., Roy, C., Schoemaker, R., Hazekamp, A., Den Hartigh, J., Bender, J., . . . Van Gerven, J. (2008). Effect of intrapulmonary tetrahydrocannabinol administration in humans. Journal of Psychopharmacology, 22(7), 707-716. doi:10.1177/0269881108089581 